\title{
Immigrant Wage Differentials, Ethnicity and Occupational Segregation
}

\author{
Robert J. R. Elliott* and Joanne K. Lindley**
}

\section{Summary}

We investigate occupational attainment as well as estimating earnings differentials for nonwhite migrants and non-white natives including occupational effects. We control for the occupational selection of immigrants and compare across native and immigrant groups. Relative to white natives, we find no evidence of an ethnic pay disadvantage for white and South Asian Professional workers. Although occupational segregation and other human capital and socio-economic factors provide a partial explanation for the raw earnings differential, evidence of ethnic based disadvantage in most occupations persists.

Word Count: approximately 11,745 including tables.

Keywords: Discrimination, earnings, occupation.

JEL: J6, J7

Acknowledgement: We would like to thank the Editor and the three referees for their invaluable suggestions. Also we are grateful to Derek Leslie, Ken Clark and Steve McIntosh, as well as participants at seminars at the University of Birmingham and University of Sheffield. The usual disclaimer applies.

* Robert J. R. Elliott is a Senior Lecturer in the Department of Economics, University of Birmingham.

** Joanne Lindley is the corresponding author and is a Senior Lecturer in the Department of Economics, University of Sheffield. Email j.lindley@shef.ac.uk, Fax Number + 44114222 3458 


\section{Introduction}

The political debate over immigration remains as heated as ever. The Prime Minister recently stated in a Home Office (2005a) report Controlling our Borders: Making Migration Work for Britain that "Managed migration is not just good for this country, it is essential for our continued prosperity" (pg. 5). Excluding Scotland and Ireland, the 1851 Census shows that about 0.6 percent of the population were immigrants rising to around 3.3 percent by the time of the 1951 Census. As of 2001, 8.3\% of the UK population are classified by the UK Census as foreign born, up from 6.7\% in 1991.

We revisit the earnings discrimination debate to examine the role of the occupational segregation of male immigrants as a possible explanation for the proportion of the wage gap that is currently considered in the existing literature to be attributed to racial disadvantage. Studies have generally shown that some of the observed pay disadvantage to non-whites can be explained by differences in human capital endowments and socio-economic characteristics (Blackaby et al. 1998; 2006). For example, although educational attainment within the non-white group varies considerably (Battacharya et al. 2003 and Connor et al. 2003), on average minority ethnic groups tend to have lower quality qualifications than whites, although the educational achievement of minorities has been increasing.

Amongst others, Blackaby et al. $(1998 ; 2006)$ show there is an element of the observed earnings disadvantage to non-whites that remains unexplained and it is this component that is assumed to contain elements of ethnic discrimination, cultural attitudinal differences, as well as disadvantage based on country of birth (Chiswick 1978). Employer discrimination based on ethnicity can occur out of prejudice or ignorance about ethnic background (Becker 1971) but also as a consequence of employers adversely making generalisations on unknown productivity levels at the recruitment stage for culturally heterogeneous groups (Phelps 1972). Both of these ideas can lead to lower non-white pay and job market segregation.

The most widely used methodology for analysing disparities in the economic performance of alternative sets of individuals is decomposition analysis. In the literature the standard application is to apply this methodology to different ethnic or gender groups and/or immigrants and to estimate the extent of any job market discrimination. With a current UK 
government committed to eliminating racial discrimination, an understanding of the determinants of earnings differentials and the extent of any such discrimination is vital. Consequently, this paper explores occupational attainment for immigrants and tries to isolate the unexplained earnings disadvantage for immigrants based on ethnic differences from that based on human capital and socioeconomic characteristic differences, including potential occupational selection into lower paying jobs. We allow for differences across immigrant status by treating White, Black, South Asian and Other non-white immigrants as separate groups. Although ethnic differences are likely to exist within these broadly defined groups, data limitations prevent further disaggregation. Often it is necessary to aggregate non-white native groups for similar reasons. We concentrate on male immigrants in order to avoid further complications associated with selection into economic activity based on cultural differences in female attitudes to marriage and the presence of children (Lindley et al. 2004).

In this paper we demonstrate that a proportion of the immigrant earnings gap can be explained by the occupational segregation of migrants and ethnic minorities. The raw data suggest that UK immigrants are over-represented in high and low paying occupations. This led us to question, for the first time in a UK study, whether the earnings disadvantage of non-white immigrants disappears once comparisons are made within occupational groups. This would suggest that the earnings disadvantage that we observe at the mean is a consequence of occupational segregation.

First, we show that, conditioning on differences in human capital and socio-economic characteristics, ethnic minority native born and immigrant men are less likely to be employed in the higher paying professions (such as Professional, Managers and Associate Professionals) relative to white native men. This suggests that the observed overrepresentation of immigrants in high paid occupations is a consequence of better employment enhancing characteristics on average, compared to native white native men and that unexplained ethnic disadvantage in occupational attainment exists. Second, we find that non-white immigrants and non-white natives under perform in terms of earnings, compared to white immigrants and white natives, even after controlling for language, cohort effects and typical human capital and socio-economic characteristics; as well as immigrant selection into lower paying occupations. Third, we demonstrate that the over-representation of non- 
white immigrants in low paid occupations, perhaps based on historical, cultural and networking reasons or issues related to over-education and employment discrimination, can explain a significant proportion of the differences in mean earnings between white and nonwhite immigrants whilst a degree of the unexplained ethnicity pay disadvantage persists.

The remainder of this paper is organised as follows: Section 2 briefly provides some background information on UK immigration patterns and reviews the relevant literature. Section 3 outlines the estimation procedure; Section 4 describes the data; Section 5 presents the results along with some sensitivity analysis; and Section 6 concludes.

\section{Background Information}

Historical records show that Britain has always had a substantial immigrant population, but until fairly recently this was mainly of white immigrants. The 1951 Census shows that approximately half of Britain's immigrants came from countries with large white populations such as Canada, Australia and New Zealand, the so-termed Old Commonwealth (see Census of Population, 1951, Vol. 23, table 39 and table 33). The arrival of large numbers of non-white immigrants to Britain is a major new feature of the post-war period. Initially these were mostly from the Caribbean. However, Bell (1997) shows that from the late 1950s there were growing numbers from India, which rose to a peak in the 1960s. After the Caribbean and Indian waves, immigration to the UK surged from Pakistan, which peaked in the 1970s and also from Bangladesh which reached its height in the 1980s. At this time large numbers also arrived from Hong Kong. Since the mid 1980s these waves have subsided and the sources of net immigration have become more diverse.

A significant proportion of the change in the national-origin mix of Britain's immigrant cohorts can be attributed to changes in immigration legislation. The 1948 British Nationality Act restricted British subject status to the newly independent states that still remained within the Commonwealth. Work permits were not required for immigrant workers from the Commonwealth. As a result, the 1950s and 1960s saw increases in immigrants from India, East Africa, the Caribbean and Pakistan. However the 1971 Immigration Act placed Commonwealth citizens in the same position as other aliens and in 1986 an advance visa system was introduced to control the entry of immigrants from India, Pakistan, Bangladesh, 
Nigeria and Ghana. Coleman and Salt (1992) use data from the Home Office to show a decline in the number of individuals entering Britain on work permits. Numbers fell from 36,000 in 1973 to less than 16,000 in the early 1980 s.

Membership of the European Community imposed further ex-colonial immigration restrictions, with free passage for EC citizens after 1973. Hence the 1980s saw a reversal in immigration origins with large declines in the flow from India and East Africa and rises in the numbers coming from Europe. The 1988 Immigration Act gave officials the power to exclude and deport any immigrants from British dependent territories. Immigrants had to show that they possessed the means to support themselves and their families without the need for public assistance.

Increasing numbers seeking asylum had become a phenomenon of the 1980s and 1990s. Prior to this, most British asylum seekers were from Communist countries in Eastern Europe. Recently British asylum claimants come from a far wider range of countries with those individuals from countries with no colonial or linguistic connections with Britain increasing. A report from the United Nations High Commissioner for Refugees (2001) showed that the main applications in Europe came from the Federal Republic of Yugoslavia (10.3 percent), Iraq (8.4 percent), Afghanistan (7.0 percent), Iran (6.6) and Turkey (5.7 percent).

In 1993 the Asylum and Immigration Act aimed to lower the number of individuals seeking asylum. This statute doubled rejection rates by removing the right to appeal if refused entry. The most recent Act is the 1999 Immigration and Asylum Act. This removed the right to all state and local authority benefits from those claiming asylum and from those who remained after being rejected. The Act also introduced the provision of accommodation on a 'nochoice' basis (See the report by the United Nations High Commission for Refugees, 2001). This involved the dispersal of asylum seekers to accommodation around the country.

In short, recent waves of UK immigration have become much more ethnically diverse. Consequently empirical studies have often focused on racial disadvantage by addressing differences in earnings and employment outcomes across ethnicity. In general, studies tend 
to show that non-white groups experience some degree of unexplained disadvantage, part of which has been attributed to ethnic discrimination (Blackaby et al. 1998 and 2002). However, understanding the origins of disadvantage is complicated. For example, Lindley and Lenton (2006) show that ethnic minority immigrants are more likely to experience overeducation compared to white natives. Over-education occurs when individuals are employed in a job for which they are over-qualified and consequently experience lower pay compared to those who are efficiently matched into a suitable occupation (see e.g. Sloane et al. 1999, Dolton and Vignoles 2000 and Hartog 2000). It is not clear how much of the occupational disadvantage faced by immigrants arises out of choice, network effects and economic conditions at the time of arrival (Bauer et al. 2002, Heitmueller 2003 and Pedersen et al. 2004) or because of under-valued foreign qualifications and racial discrimination from employers at the recruitment stage (McIntosh and Smith 1974, Brown and Gay 1985 and Riach and Rich 1991; 1992). Although this type of discrimination has declined in the UK over successive studies, evidence suggests it has not disappeared.

Of the existing research into racial pay differences, Blackaby et al. (1998; 2002; 2006) and Reed and Chang (2003) examine racial and ethnic differentials for the UK and California respectively and both demonstrate that non-white ethnic minorities have lower earnings and higher unemployment rates that their white counter-parts. In a study that touches on a number of the themes of this paper, Constant and Massey (2003) demonstrate that although guest workers in Germany experience significant discrimination in the process of occupational attainment, if occupational status is held constant much of the discrimination in earnings attainment is removed (one explanation is that guest workers are directed into less favourable occupations by a discriminating society). Two papers concentrate on UK immigrant wage gaps: Chiswick (1980) using the General Household survey; and Shields and Wheatley-Price (1998), using the Labour Force Survey. After controlling for human capital and socio-economic characteristics, both find significant differences between white and nonwhite immigrant earnings and suggest ethnic discrimination to a significant proportion of the earnings gap. 


\section{Modelling Framework}

Given that some immigrant workers may face disadvantage when applying for jobs we begin by using a sample of working men to compare probabilities of different levels of occupational attainment for different ethnic and immigrant groups conditional on a vector $\mathbf{C}_{\mathbf{i}}$ of human capital and socio-economic characteristics (human capital, region of residence etc., survey year, arrival cohorts etc.). $\mathbf{C}_{\mathbf{i}}$ also includes an intercept term and, since they are of direct interest, dummy indicators for white immigrants; Black natives; South Asian natives; other non-white natives; Black immigrants; South Asian immigrants and other nonwhite immigrants. White natives are thus the default group. We also include in $\mathbf{C}_{\mathbf{i}}$ a variable which is defined as years since migration for non-natives and zero for natives and also the square of this variable. The lack of meaning of years since migration for natives is effectively taken care of since the variable can now be alternatively thought of as a term for interaction between years since migration and a dummy for non-native status. The variable captures convergence or divergence of initial immigrant differences towards natives or can be interpreted as evidence of differences in the age-earnings locus of immigrants and natives. Its effect is allowed to vary for white and non-white immigrants by further interacting it and its square with the white immigrant dummy

We estimate a multinomial logit where the qualitative dependent variable $Z_{i}$ can take on any of the $H$ possible values $\mathrm{Occ}_{1}, \ldots, \mathrm{Occ}_{\mathrm{H}}$, each corresponding to a different occupation. We therefore estimate,

$$
p_{i h}=\operatorname{prob}\left(Z_{i}=O c c_{h}\right)=\frac{\exp \left(\mathbf{\alpha}_{\mathbf{h}} \mathbf{C}_{\mathbf{i}}\right)}{1+\sum_{k=1}^{H-1} \exp \left(\mathbf{\alpha}_{\mathbf{k}} \mathbf{C}_{\mathbf{i}}\right)} \text { for } h=1,2 \ldots H-1
$$

and

$$
p_{i H}=\frac{1}{1+\sum_{k=1}^{H-1} \exp \left(\mathbf{\alpha}_{\mathbf{k}} \mathbf{C}_{\mathbf{i}}\right)} \text { to ensure that } \sum_{h=1}^{H} p_{i h}=1
$$


Equation (1) is estimated for a full sample of immigrants and naives, where $p_{i n}$ is the probability that individual $i$ will be employed in occupation $h$ and $\boldsymbol{\alpha}_{\mathbf{k}}$ is a vector of coefficients corresponding to the kth occupation.

Following this, we estimate earnings equations based on the model by Chiswick (1978; 1980). We estimate both a single equation and separate equations for immigrants and natives. We begin by estimating a single earnings equation on a pooled sample of immigrants and natives,

$Y_{i}=\boldsymbol{\beta} \mathbf{x}_{i}+\varepsilon_{i}$

where $Y_{i}$ is $\log$ of gross weekly earnings for individual $i, \mathbf{x}_{\mathbf{i}}$ is a vector of worker characteristics similar to $\mathbf{C}_{\mathbf{i}}$ and also includes an intercept and the ethnic-immigrant group dummies. Following Chiswick $(1978 ; 1980)$, the significance of years since migration in equation (2) for the pooled sample provides evidence of assimilation of immigrant earnings towards those of natives.

Following Neuman and Silber (1996) we examine the effect of occupational segregation by estimating equation (2) separately for individual 1-digit occupations. This approach allows the parameters of the earnings functions to vary across occupations. We can then compare parameters from the pooled 'all occupations' model to those estimated separately by 1-digit occupation classification to see whether the immigrant-ethnic effects are the same across all $H$ occupational categories. We do this first for a pooled sample of immigrants and natives, followed by separate equations for the two groups.

For the immigrant equations, occupational selectivity effects may be particularly important in the context of comparing immigrant pay penalties. Consequently, we correct for occupational selection using the Heckman (1979) approach. In the probit selection equations and in order to identify the earnings equation we additionally use as identification parameters changes in immigration policy at year of arrival. We identify five distinct immigration policy regimes; (1) before the 1971 Immigration Act; (2) between the 1972 and the 
1988 Immigration Act; (3) between 1989 and the 1993 Asylum and Immigration Act; (4) between 1994 and the 1999 Asylum and Immigration Act and (5) after 1999. Consequently we included 4 dichotomous variables for year of arrival within these regimes, with arrived before 1971 as the default category.

Following this we estimate separate earnings functions,

$Y_{i}^{r}=\boldsymbol{\beta}^{\mathbf{r}} \mathbf{x}_{\mathbf{i}}^{\mathbf{r}}+\varepsilon_{i}^{r}$

for each immigrant group $r$. The vector $\mathbf{x}_{\mathbf{i}}$ of worker characteristics now also includes occupation group dummies. Indexed by $r$ we have the five key immigrant groups: natives; white immigrants; Black immigrants; South Asian immigrants and a composite non-white immigrant group. This latter group contains Black immigrants, South Asian immigrants and other non-white immigrants. Small sample sizes prevented separate estimation for the 'other' immigrant group.

We investigate how much of the observed differential in mean log earnings between immigrants and natives can be attributed to differences in the occupational distribution of each group. Following Oaxaca and Ransom (1994), we decompose the differential in mean log earnings between any two groups $r$ and $t$ using,

$\bar{Y}^{r}-\bar{Y}^{t}=\left[\hat{\boldsymbol{\beta}}^{*}\left(\overline{\mathbf{X}}^{\mathbf{r}}-\overline{\mathbf{X}}^{\mathbf{t}}\right)\right]+\left[\overline{\mathbf{X}}^{\mathrm{r}}\left(\hat{\boldsymbol{\beta}}^{\mathrm{r}}-\hat{\boldsymbol{\beta}}^{*}\right)-\overline{\mathbf{X}}^{\mathbf{t}}\left(\hat{\boldsymbol{\beta}}^{\mathrm{t}}-\hat{\boldsymbol{\beta}}^{*}\right)\right] \quad=H C+D$

It is necessary for the variables in $\mathbf{x}$ to be the same across groups $r$ and $t$, therefore cohort effects cannot be included in native/immigrant decomposition but are included in immigrant white/non-white decompositions. $\hat{\boldsymbol{\beta}}^{\mathbf{r}}$ and $\hat{\boldsymbol{\beta}}^{\mathrm{t}}$ are estimates of the corresponding parameters in model (3) for immigrant groups $r$ and $t$. The non-discriminatory coefficient vector is given by $\hat{\boldsymbol{\beta}}^{\boldsymbol{*}}=\boldsymbol{\Omega} \hat{\boldsymbol{\beta}}^{\mathbf{r}}+(1-\boldsymbol{\Omega}) \hat{\boldsymbol{\beta}}^{\mathbf{t}}$ where $\boldsymbol{\Omega}=\left(\mathbf{X}^{\mathbf{r} \mathbf{}} \mathbf{X}^{\mathbf{r}}+\mathbf{X}^{\mathbf{t}} \mathbf{X}^{\mathbf{t}}\right)^{-1} \mathbf{X}^{\mathbf{r}} \mathbf{X}^{\mathbf{r}}$ is the appropriate weighting matrix (Oaxaca and Ransom 1994). Oaxaca (1973) and Blinder (1973) provide the origins for this approach. We do not correct our estimates for employment selection bias for two reasons: first, corrected estimates tend to rely heavily upon the usually arbitrarily 
chosen instruments used to identify the earnings equations. Moreover, our selectivity corrected immigrant only estimates show that ethnic earnings penalties are generally robust to selection effects. Second, the component of the raw differential that can be attributed to differences in selectivity tends to be negligible. Blackaby et al. (2002) show that correcting for selectivity bias changes the white/non-white earnings differential by approximately one percent.

The $H C$ term in equation (4) is the difference in the mean log earnings between the two groups that can be attributed to differences in earnings related characteristics contained in the vector $\mathbf{x}$. Since the model is linear, the characteristics component can be further decomposed into its composite human capital and socio-economic characteristics. The $D$ term, or the coefficient effect, is the raw mean differential that can be attributed to differing marginal effects, $\hat{\boldsymbol{\beta}}^{r}, \hat{\boldsymbol{\beta}}^{\mathrm{t}}$, between the two groups. This is the unexplained component and is considered to contain elements of discrimination. Concern over the identification problem associated with the decomposition of the coefficient effect (see e.g. Jones 1983), means that the majority of empiricists no longer attempt to decompose the coefficient effect. Yun (2003) provides a discussion and a possible solution to the identification problem in estimations of detailed earnings equations.

Finally, following Neuman and Silber (1996) we further decompose the mean immigrant log earnings differential into an occupational segregation component, $S$, as well as a characteristic, $H C^{\prime}$ and coefficient effect, $D$ ' that assume no occupational segregation exists,

$\bar{Y}^{r}-\bar{Y}^{t}=S+H C^{\prime}+D^{\prime}$

To do this we begin by estimating occupational segregation using equation (1). The component of the mean immigrant log earnings differential that can be attributed to occupational segregation can be derived using,

$S=\sum_{h}\left[\left(\bar{p}_{h}^{r}-\bar{p}_{h}\right) \cdot \bar{Y}_{h}^{r}-\left(\bar{p}_{h}^{t}-\bar{p}_{h}\right) \cdot \bar{Y}_{h}^{t}\right]$ 
where $\bar{Y}_{h}^{r}$ are occupation specific average log earnings of group $r$ and $\bar{p}_{h}$ is the predicted probability for occupation $h$ evaluated at the sample means of the covariates, derived by estimating equation (1) on the full sample which assumes no occupational segregation (excluding immigrant and ethnic dummies). Similarly we derive $\bar{p}_{h}^{r}$ by estimating equation (1) on the immigrant group $r$ where occupational segregation for groups $r$ and $t$ is permitted. Hence, the non-occupational segregation characteristic and coefficient components are generated by weighting occupation specific characteristic effects $H C_{b}^{\prime}$ and unexplained (coefficient) effects $D_{h}^{\prime}$ by the non-segregation terms $\bar{p}_{h}$ and summing across all $h$ occupations. Thus,

$$
\begin{aligned}
& H C^{\prime}=\sum_{h} \bar{p}_{h} \cdot H C^{\prime}{ }_{h} \\
& D^{\prime}=\sum_{h} \bar{p}_{h} \cdot D^{\prime}{ }_{h}
\end{aligned}
$$

where $H C_{b}^{\prime}$ and $D_{b}^{\prime}$ are derived by estimating equation (3) separately for each occupation. The only drawback of this particular method is that it requires estimation of occupational specific earnings equations for separate immigrant groups, where sample sizes are often rather small.

\section{Data}

Our data are drawn from the Office for National Statistics (ONS)'s Quarterly Labour Force Survey (QLFS) for the period 1993 to 2003. Details of the sampling methodology, questionnaires and SOC90 occupation codes are available from the ONS at http://www.ons.gov.uk. Given that the QLFS is not a longitudinal dataset the data can only be used as a pooled cross-section. The clear advantage of using the QLFS is its size. The QLFS is the only UK survey to provide adequate sample sizes for analyzing immigrant and ethnic minority groups over time. Furthermore, the sampling design implies excellent coverage for immigrants since it uses stratification and avoids clustering, thus providing good geographical reporting. This is important since many immigrants are concentrated in specific areas and a clustered sampling design could well omit coverage of key immigrant conurbations. 
We analyse gross weekly earnings for full-time male workers aged 23 to 65 . Given that the QLFS does not ask questions on parental background, we define an immigrant as someone who claims their country of birth was outside the UK, so that native includes second generation immigrants. As the focus of this paper is to estimate the effect that occupational attainment has on earnings, cell size considerations mean that it is not possible to split natives or immigrants into detailed individual ethnic groups or countries of origin to the degree undertaken by Blackaby et al. 2006.

We exclude the self-employed and all immigrants who were direct entrants into the UK education system since these immigrants would have arrived in the UK as children or students. This means we include only those immigrants who made a conscious decision to migrate. We do this because non-white immigrants who arrive as children or into higher education possess some degree of British education and therefore tend to have similar profiles to non-white natives.

Throughout this paper we use a quadratic in years of schooling as a measure of human capital. Although the QLFS collects information on the qualifications held by the respondent, all foreign qualifications are coded into the one category of "other" qualification regardless of the level. It is therefore not possible to competently compare foreign and UK qualifications. However, comparing years of schooling across native qualification levels suggests that schooling is a good proxy for qualifications, although we are unable to account for the non-equivalence between academic and vocational qualifications. Our sample shows that native-born respondents with a degree have on average 17 years of schooling, compared with 14 years and 12 years for respondents with A-levels and O-levels respectively. There is also some potential for ability bias if immigrants are of higher ability for a given level of schooling, although correcting for occupational selectivity should control for some of this. Furthermore, we find that white natives hold on average 13 years of schooling compared to 15 years for non-white natives and immigrants, as detailed in Table A1 of the Appendix. Given that occupational attainment is conditional on qualifications, we presume that returns to schooling may be reduced once occupational controls are included in our model. 
Table 1 provides a frequency table for the distribution of 1-digit occupations for our six groups. Occupations have been ranked in descending order of total average weekly pay. The overall occupational distribution is very similar to that for white natives which is not surprising given the relative size of this group. Compared to white natives, four of the other five groups are over-represented in the highest paid Professional occupations (that includes doctors and academics). However, $40 \%$ of non-white migrants are in the bottom three occupations (46\% and 45\% for Blacks and South Asians respectively), compared to just 23\% for white migrants. For both white and non-white natives 30\% are employed in the bottom three occupations. Hence there appears to be some support for the proposition that nonwhite immigrants are generally over-represented in the lower paid professions, whilst white immigrants are over-represented in the top two highest paying occupations ( $43 \%$ employed as Professionals and Mangers). Such a pattern might be consistent with an immigration policy that makes it easier to get a visa if you are in a highly desired or high skilled occupation or in a low paid occupation where labour shortages currently or previously existed.

Table 2 presents mean log weekly earnings by occupation. All earnings data were deflated to a common year and models were estimated using hourly wages with qualitatively similar results. Perhaps surprisingly, non-white immigrants receive not only the lowest earnings for certain occupational groups and also overall, but also the highest average pay for the highest earnings Professional groups (this is even more pronounced for South Asians). More generally, across the majority of occupations white immigrants tend on average to earn more than white natives (Personal and Protective, Sales and Other occupations being the three exceptions). The reverse holds for non-whites (immigrants and natives), who tend to earn less, on average, than white natives (immigrant Professionals being the only exception). Although non-white natives earn on average more than non-white immigrants, the differences are small.

Other characteristic differences between ethnic groups are detailed in Table A1 in the Appendix. These show that non-white immigrants tend to be slightly older on average compared to white natives and immigrants. Immigrants (and native born non-whites) are clearly over-represented in the South East compared to white natives, as well as being more 
likely to be employed in the Service sector perhaps reflecting the high concentration of immigrants in the Capital, based perhaps on historical immigration patterns and established network effects. The arrival cohort variables, based on changes in immigration policy and years since migration comparisons, show that that Black immigrants arrived in the UK first and supports the findings of Bell (1997). However, there is a possible issue of undercounting for those who arrived in the UK prior to 1970. A comparison between the census and QLFS data of those over 30 years of age shows that the QLFS under-records pre-1970 migrants by up to $6 \%$. See Home Office (2005b) for details.

\section{Results}

To investigate the relationship between occupational attainment and earnings, we begin by estimating equation (1) as described above, using a multinomial logit model for a sample of immigrants and natives. We then estimate equation (2), initially for a sample of pooled immigrants and natives and then also separately for immigrants and natives. All estimates are derived using STATA/SE 9.2 statistical software by Stata Corp (2005). In the results Tables 3, 4 and 5 we include quadratics in years of schooling and years of migration but focus on presenting the effects of ethnic and immigrant status. We emphasise that these effects are relative to the default category British born white for Tables 3 and 4 and white in the separate equations of Table 5. However, we include as controls in the specification of both occupation and earnings equations a quadratic in age and years since migration, and represented by dummy categorical variables are; marital status; three employment tenure categories; region of residence; three employment sectors; and year of survey. For the occupation equations (1) with key results in Table 3 we further include 5 cohort arrival dummies (with the reference default before the first 1971 Immigration Act) and an indicator of whether English is spoken as a first language in country of origin. These variables are also included in the results of Table 5 in the earnings equations restricted to immigrants.

\section{5a. Occupational Attainment}

Table 3 provides the marginal effects for the key variables from the occupational attainment multinomial logit equation. Marginal effects for continuous variables are calculated as the

derivative of the predicted probability $\hat{p}_{i h}$, whereas categorical variables are evaluated as the 
difference of $\hat{p}_{i h}$ relative to the default category, both evaluated using the mean characteristic vector $\bar{C}$. The default occupational category is 'Other' occupation. Recall that Table 1 showed white immigrants to be over-represented in the top two, whilst nonwhite immigrants were over-represented in the bottom of the occupation groups arranged by level of earnings. However, for Professionals, Mangers and Associate Professionals Table 3 shows that relative to white natives, most non-white natives and all immigrant groups experience an unexplained penalty in terms of attaining employment in these higher paid occupations. Also, at the lower end of the occupational distribution, relative to white natives, South Asian immigrants are 25 percentage points more likely, whilst Black immigrants are 16 percentage points more likely, to be employed in Plant and Machine jobs.

In terms of our other controls, years since migration is generally not significant with some evidence of convergence between natives and the occupational attainment of white Professional immigrants and non-white clerical workers. Contrariwise, there is evidence of divergence for non-white Professional immigrants. This suggests that in general immigrants initially face a probability of being employed as a Professional lower than that of natives. The only exception appears to be white immigrants where it is higher than native Blacks. For non-white immigrants this probability diverges from that of natives and diminishes with time spent in the UK, insofar as dominant linear term in the quadratic effect is negative at -0.005 . For white immigrants the quadratic effect has $0.002(-0.005+0.0007)$ for the linear term and quadratic term is negligible and so the probability increases and converges to that of natives. Whilst this might suggest that racial employment disadvantage increases over time for the non-white professional group, it should be noted that because the data are pooled crosssections this might be a consequence of relatively higher migration flows into and out of the country, for this occupation group. Unfortunately, detailed data on out-migration for the UK are not available but our data show larger in-flows in recent times, since 45 percent of non-white Professionals migrated in the last 12 years, compared to 34 percent for nonProfessional non-white immigrants and 41 percent for white Professionals.

The effect of schooling on occupational attainment shows that each year of schooling increases the chances of being in a Management job by around 20 percentage points, 
compared to around 11 percentage points for Professionals and 9 percentage points for Associate Professionals. Not surprisingly, schooling reduces the likelihood of being in a job at the bottom end of the occupational pay distribution (with Clerical being the exception).

\section{5b. Earnings Equations.}

Table 4 presents key results for equation (2) estimated on a pooled sample of immigrants and natives. The first column provides the results for the full sample. Estimates show that over and above the socio-economic characteristics included in the model, all non whites (immigrants and natives) experience lower pay on average relative to white natives. The largest penalties are experienced by South Asian immigrants (0.393 log points), followed by Black immigrants (0.348 log points) and other non-white immigrants (0.283 log points). White immigrants suffer no such penalty.

The other 9 columns in Table 4 present key estimates for equation (2) estimated separately by 1-digit occupation category in order to compare within occupation pay differentials. Again, these appear in order, from left to right, by descending average occupational pay. The first column shows that over and above human capital and employment enhancing characteristics, significant immigrant pay penalties exist for Black and other non-white immigrant Professionals, and that non-white differentials assimilate with years spent in the UK. White immigrants employed in managerial jobs generally earn 0.14 log points more on average, whilst the three non-white immigrant groups all earn around 0.13 log points less than white native managers. There is also some evidence of ethnicity and immigrant differences for Associate Professionals, with Immigrant South Asian (0.23 log points less) and Black immigrants (0.22 log points less) exhibiting the highest penalties. At the lower end of the occupational distribution, there is further evidence of ethnic disadvantage both to British born and immigrant non-whites.

In general assimilation effects appear to be small, but significant initial penalties for Black and Other non-white immigrants amongst Professionals appears to diminish over time, whereas there is evidence of worsening over time for the significant initial penalties for South Asian and Other non-white Managerial, non-white Personal \& Protective and South Asian Clerical groups. Interestingly, the interaction between years since migration and the 
white dummy variable is not significant for Managers, so that the negative and significant years since migration affect holds for both white and non-white immigrants. This suggests that the advantage of white immigrant Managers over their white native counterparts diminishes over time. Similarly, white immigrants employed in other occupations initially earn less than their native counterparts, although this disadvantage diminishes in the same way as it does for other non-white immigrants employed in similar jobs. However, as already noted, these pooled cross-section data cannot control for occupational differences in immigration flows.

Returns to schooling show returns to be higher for Managers and Associate Professionals. As expected, lower paying occupations experience smaller education returns the exception being Personal and Protective occupations.

Table 5 provides key occupational estimates for split samples of immigrants and natives. Chow tests for parameter stability comfortably reject the null hypotheses of common slope coefficients between immigrants and natives. These tests suggest that the structural determinants of native earnings differ to those for immigrants. Hence Table 5 allows the parameters on the controls (schooling, age, marital status, employment tenure categories, region of residence, employment sector and survey year) in the occupational specific log earning equations to differ across immigrants and natives, whereas Table 4 imposes the restriction that these parameters are the same for immigrants as for natives.

The pooled occupational estimates are discussed first and the subsequent occupational specific estimates appear in descending order of average pay. It was necessary to group Sales professions in with Other occupations because of the small sample size of immigrants. The first column provides estimates for natives where the default category is white natives. The second column refers to immigrants only where the default category is white immigrants. The third column provides selectivity corrected earnings estimates for immigrants using changes in immigration policy at year of arrival to identify the wage equation. The final column provides key coefficient estimates from the occupational selection probit equations. 
Looking at the first column, ethnic pay differentials are similar to those discussed in Table 4 and therefore they are not discussed again here. The second column shows that relative to white immigrants, all non-white immigrants do comparatively worse. What is also interesting is the comparison of schooling returns across natives and immigrants in columns one and two. In general immigrants exhibit much lower returns to schooling which might indicate that foreign gained qualifications are not valued as highly in the UK relative to UK gained qualifications. However, examination of the occupational specific results show that there is no difference between the native and foreign schooling effect for Professionals, and it is reversed for Craft and Related, as well as Other groups.

Compared to white immigrants there is some evidence of ethnic disadvantage for non-white immigrants, the reference category for these analyses, where this is across all occupations, although differences are smaller for Professionals. Black immigrants experience more racial disadvantage when employed in Craft and Related occupations and the least in Professional jobs. South Asian immigrants suffer the most when employed in Personal \& Protective jobs.

The third column shows occupation selection corrected earnings estimates, with the selection equation estimates provided in the final column. Generally ethnic differences are fairly robust to sample selection. The selection coefficient (rho) is the full information maximum likelihood estimate of the correlation between the error term in the log earnings equation and the error term in the occupation selection probit. These show that occupational selection effects are not significant in 4 of the 8 occupations. Selection effects are negative and significant for Associate Professionals, Clerical and Other occupations and positive and significant for Plant and Machine. This suggests that there is negative correlation between the error term of equation (3) for immigrants and the error term of a selection equation for Associate Professionals, Clerical and Other jobs. So that there exists some unobservable characteristic that simultaneously increases the probability of employment in these occupations (relative to the other occupations) whilst also reducing earnings. One could conjecture something like poor motivation or family commitments that are over and above the controls used in the model. The only occupations to show any positive correlation between occupational attainment and earnings is that of Plant and Machine operatives, 
whereby unobservable ability might explain the increased occupational likelihood and simultaneous higher earnings for this group.

In general, it is Associate Professional and Clerical returns to schooling that are the most sensitive to sample selection bias, suggesting negative returns to immigrants once they gain employment (for Associate Professionals, and ignoring the small quadratic effect, a linear effect of $-0.21 \mathrm{log}$ points per year compared to a positive $0.14 \mathrm{log}$ points per year for natives). One explanation is that these occupation categories may act as feeder occupations to the Professional category and therefore contain foreign graduate immigrants that are transiently over-educated until they acquire UK specific human capital and attain a suitable occupation match for their foreign gained qualifications. In fact the raw data show that 1.24 (1.10) percent of immigrants employed in Associate Professional (Clerical) jobs are likely foreign graduates (whereby foreign graduate is defined as has foreign gained qualifications and who left school after age 20), compared to 0.47 percent across Craft \& Related, Personal \& Protective, Plant \& Machine and Sales \& Other jobs. In addition, these Associate Professional and Clerical foreign graduates hold less employment tenure (6.81 years) on average, compared to non-graduate immigrants (9.06 years) employed in the same 1-digit occupation group.

The probit selection equations in the final column also demonstrate incrementally higher positive effects of schooling on selection probabilities for higher paying jobs with the largest occupational effects being on selection into Managers and Associate Professionals. Schooling is not significant for gaining employment into the lower skilled Craft, Personal/Protective and Other occupations. Relative to arriving before the first immigration policy regime change in 1971, the immigration policy change variables used to identify the earnings equations are positive and significant for Personal/Protective and Other, whilst they are negative and significant for Professional, Associate Professional, Craft \& Related and Plant \& Machine occupational attainment. This suggests that changes in British immigration policy has influenced the occupational attainment of immigrants with more recent immigrants being more likely to work in the relatively lower skilled Personal/Protective and Other occupations and less likely to work in Professional, Associate Professional, Craft \& Related and Plant \& Machine jobs. 
Finally, the selection equations also show that non-white immigrants do experience substantial occupational disadvantage in terms of attaining the higher paid Professional, Management, and Associate Professional jobs, relative to white immigrants. Although earnings differentials are negligible, South Asian immigrants are less likely to be employed in Professional jobs compared to white immigrants. Contrariwise, non-white immigrants are more likely than white immigrants to attain employment in lower paying professions, with Black immigrants being more likely to be employed in Other and Plant and Machine jobs.

\section{5c. Decomposition Analysis}

We investigate occupational segregation further using decomposition analysis. This involves estimating separate equations for white natives; non-white natives; white immigrants; Black immigrants; South Asian immigrants and the composite non-white immigrant group. The estimation does not correct for selection effects for reasons previously explained. We thus decompose the raw mean log weekly earnings differentials from the final row of Table 2 controlling for differences in the occupational distribution of our groups.

Table 6 decomposes average earnings differences between immigrant groups and the base category of white natives. Given that occupation is potentially endogenous, the table is split into two panels (a) that use equations which exclude occupation controls in the decomposition and (b) which includes the occupation effects. The first row of both panels provides the raw log pay differentials from Table 2. In panel (a), compared to white natives, non-white natives exhibit a small negative characteristic effect meaning that, based on characteristics alone, non-white natives should actually do better than white natives. The subsequent rows show that this result is mainly due to the large characteristic effects on schooling and regional distribution. However, these positives are offset by detrimental effect of age, tenure, sector and marital status. Hence, non-white natives benefit from higher levels of schooling (acknowledging that we are unable to determine the exact labour market value of schooling because we do not determine between academic and vocational qualifications) and the fact that the affluent South East, where wages are generally inflated and the economy buoyant, is home to a large percentage of Britain's ethnic minorities. The significant age effect is a result of the much younger non-white native group where age is 
conditioned by previous waves of immigration. For example, the children of immigrants who arrived in 1955 would now be fifty years of age leaving few observations between fifty and retirement. Overall Column 1 indicates that the $0.06 \log$ earnings differential may be due, in part, to factors related to discrimination as there remains a large unexplained effect of 0.09 compared to a favourable non-white characteristic effect of -0.03 .

In the second column we compare white natives with white immigrants. In this case we observe a negative earnings differential meaning that white immigrants earn on average more than white natives. The unexplained coefficient effect is also small meaning that there appears to be only a small amount of job market discrimination against white migrants. The largest beneficial characteristic effects are schooling and region.

A rather different picture emerges when we decompose the $0.16 \mathrm{log}$ earnings differential between white natives and non-white immigrants. In this case the earnings differential consists of a large unexplained component partially offset by a favourable characteristic effect (-0.18). The log earnings differential between white natives and non-white immigrants would in fact be significantly greater (0.34) if it were not for the superior earnings enhancing characteristics of immigrants. Again, schooling and region are working in favour of immigrants (and being married in this case).

The final two columns in Table 6 disaggregate non-white immigrants further into the Black and South Asians composite groups. We cannot do this for 'Other' ethnic group because these groups are too small. The raw log pay differential is larger for South Asians (0.204) compared to that for Black men (0.171). For both groups the characteristic effect is negative and again reduces what would be a larger differential if it were not for the favourable characteristics of non-white immigrants (mainly caused by higher levels of schooling and regional differences). The relatively favourable schooling levels and marriage effects are larger for South Asian than Black immigrants.

Panel (b) of Table 6 includes occupational dummies as controls. Including extra controls in the specification reduces the coefficient effect. Including occupational dummies reduces the favourable schooling effect in all cases. This suggests that occupation controls are indeed 
picking up some element of human capital. But the effect of occupation has different implications across the five decompositions. The occupation effect is favourable only to non-white natives and white immigrants. This suggests that non-white immigrants are indeed clustering into lower paying occupations even though they tend to have, on average, more schooling than white natives.

An unfavourable occupation effect is observed for all non-white immigrants although it is larger for Blacks than for South Asians. This is because of clustering in Other occupations and also Personal and Protective which tend to employ large numbers of relatively unskilled workers. Interestingly, it appears that the smaller unfavourable occupational effect for South Asians is because of clustering in Secretarial and Plant \& Machine jobs.

Given that white immigrants do better than non-white immigrants, Table 7 decomposes mean log weekly earnings between white and non-white immigrants. The advantage of this decomposition is that it allows the comparison of immigrant specific controls (such as arrival cohort effects and English speaking country of origin) across immigrant ethnic pay differences. Again decompositions are presented without (panel a) and with (panel b) occupation controls.

In the first column of panel (a) and (b) of Table 7, we see that the overall log earnings differential between white immigrants and non-white immigrants is 0.025. In panel (a) a negative characteristic effect shows that non-white immigrants have more favourable earning enhancing characteristics compared to White migrants (-0.02). As we are concentrating on immigrants only the regional effect has been greatly reduced. It is age, schooling, employment tenure and English speaking country of origin that explains any advantage to non-white immigrants. Distinguishing between Black and South Asian immigrants implies a slightly larger raw pay differential for South Asians. For both groups the characteristic effects are negative and small.

In Panel (b) the inclusion of the occupation controls has increased the characteristic effect and it is now positive for non white immigrants (0.07). Of the characteristic effect of 0.07 , the occupation component is 0.08, offset slightly by the effects of: tenure; English speaking 
country of origin; age; and years of schooling. However, our results suggest that only a small amount of the raw differential can be explained by the human capital and socio-economic characteristics that are included in our model (including English speaking country of origin and cohort effects). The majority of the observed mean earnings difference between white and non-white immigrants can be attributed to unexplained differences, which includes a component for ethnic discrimination.

Most characteristic effects are small. The largest differences between the composite characteristic effects are for differences in occupational structure. Again, relative to white immigrants, Black immigrants have an unfavourable clustering in Other occupations and Plant \& Machine, where the unfavourable clustering is in Clerical/Secretarial and Plant \& Machine occupations for South Asian immigrants. These results emphasise the importance of including occupational structure in analyses of ethnic and immigrant earnings differentials.

Finally, we provide a brief discussion of two modifications made to our sample in order to provide a sensitivity analysis for our results. For brevity, the estimates are not presented here but are available from the authors on request. Firstly, we consider any regional bias in our sample and secondly we try to take account of the lower average age of non-white natives. The large characteristic effect for region in Table 6 closes the log earnings differential between white natives and all immigrants and white and non-white natives. Whilst residents in the South-East do on average earn higher wages than those in other regions of the UK for undertaking similar work (the result we find in Table 6), this does not take account of the considerably higher costs of living in the South-East where housing, travel and food costs are also higher. Our second concern relates to the historical patterns of UK migration. This implies that there are very few non-white natives over the age of fifty.

When we decompose log weekly earnings differentials for prime age men (aged between 25 and 40) for those respondents living in the South-East of England we first of all notice that the majority of migrants live in the South East (over 60\%), so that these decompositions do not reduce sample sizes for immigrants substantially. Secondly, we find that in all cases the earnings differentials have moved in favour of white natives. One can assume therefore that there are non-economic incentives for immigrants to live and work in the Capital that might 
include informal network effects and economic conditions at the time of arrival as already discussed. Also, it is likely that visas will have been easier to obtain in high skilled occupations given changes in more recent UK immigration policy. Consequently, labour markets with relatively high levels of excess demand for such skilled labour are likely to attract more immigrants. In short, the results are broadly supportive of our previous findings and demonstrate that the occupational distribution is working favourably for white immigrants and unfavourably for non-white immigrants and natives.

\section{5d. Occupational Segregation}

Finally, we decompose immigrant pay differentials whilst controlling for occupational segregation using equations (1) and (5) to (8). The first three columns in Table 8 provide earnings decompositions for non-white natives, white immigrants, and non-white immigrants where white natives are the base group. The final column shows the decomposition between white immigrants and non-white immigrants. The controls in the earnings and occupational attainment equations are the same as those discussed earlier. Even after combining Sales with Other occupation groups, the sample sizes for the occupation specific non-white native and immigrant equations are often quite small, as Table 1 points out. Consequently this method is not favoured over the decompositions provided in Tables 6 and 7. The results show that the majority ( 0.057 of the 0.064 ) for the native born white/non-white log pay differential can be attributed to the unexplained ethnic component, with a small (0.002) occupational segregation effect. In the second column, the main components of the $0.092 \log$ pay differential between white natives and white immigrants are characteristics (0.042) and occupational segregation (0.038) with a very small component attributed to racial disadvantage. For non-white immigrants we can see that there is a large unexplained racial element of 0.252. If it were not for the favourable human capital and socioeconomic characteristics of non-white immigrants the raw differential would be much larger. The occupational segregation effect explains 0.028 of the 0.162 raw log earnings differential. Hence, relative to white natives the occupational segregation effect is virtually zero for non-white natives, favourable to white immigrants and unfavourable to non-white immigrants. 
The final column shows the differential between white and non-white immigrants where these equations also contain year of arrival and English speaking country of origin as controls. The raw ethnic differential for immigrants can mainly be attributed to the ethnic disadvantage (0.25). Moreover, the non-segregation characteristic effect is again unfavourable compared to white immigrants and is almost completely offset by the favourable human capital and socio-economic characteristics of non-white immigrants. Table 8 generally supports the findings from Tables 6 and 7 .

\section{Concluding Comments}

The main result of this paper is that immigrants are over-represented in the higher and lower pay occupational categories and that even after taking into account occupational segregation there still remains a significant ethnic pay penalty. The occupational segregation models show that the over-representation of white immigrants in the Professional category is a consequence of better employment enhancing characteristics on average compared to natives. Contrariwise, the over-representation of non-white migrants in low paid occupations may be as a result of informal network effects, over-education effects and historical or cultural ties to certain occupations but may also include an element of ethnic based discrimination that prevents them obtaining work in higher paying occupations.

In addition to the earnings disadvantage there is also evidence that an ethnic disadvantage befalls non-white immigrants who attempt to gain employment in higher paying occupations compared to white natives and white immigrants. We find that no earnings disadvantage exists for white and South Asian immigrant Professionals relative to white natives, although ceteris paribus, Black and Other non-white immigrant Professionals do not perform as well as their white counterparts. It is also evident from our decomposition analysis that a significant unexplained penalty for non-white natives and a larger penalty to non-white immigrants exists. In the full sample, large favourable characteristic differences partially offset the unexplained components to leave the smaller differences we observe from the raw data. These characteristics are higher levels of schooling for immigrants and the geographical clustering of immigrants into the higher paying regions (the South East). 
After controlling for differences in age structure and regional diversity, as well as controlling for occupational segregation based on multivariate analysis, a substantial component of the raw mean earnings advantage to white immigrants can be attributed to better paid occupations. In short, there is evidence that non-white immigrants are more likely than their white counterparts to find themselves employed in lower paid occupations even after controlling for human capital and socioeconomic differences. However, an important observation is that the raw disadvantage to non-white immigrants can be attributed to unexplained differences that may include elements of ethnic pay discrimination from existing employers. This supports the ideas of Becker (1971) and Phelps (1972) where racial prejudice from employers can result in lower pay and labour market segregation for some minority ethnic groups. 


\section{References}

Bhattacharyya, G. Ison, L. and Blair, M. (2003) Minority ethnic attainment and participation in education and training: The evidence, Research Topic Paper RTP01-03, London: Department for Education and Skills.

Bauer, T., Epstein, G. and Gang, I.N. (2002) Herd Effects or Migration Networks? The Location Choice of Mexican Immigrants in the U.S., IZA Discussion Paper No. 551.

Becker, G., (1971) The Economics of Discrimination, The University of Chicago Press.

Bell, B.D. (1997) The Performance of Immigrants in the United Kingdom: Evidence from the GHS, Economic Journal, 107, 333-345.

Blackaby, D.H., D.G. Leslie, P.D. Murphy and N.C. O'Leary (1998) The Ethnic Wage Gap and Employment Differentials in the 1990s: Evidence for Britain, Economics Letters, 58, 97-103.

Blackaby, D.H., Leslie, D.G., Murphy, P.D. and O’Leary, N.C. (2002) White/Ethnic Minority Earnings and Employment Differentials in Britain: Evidence from the LFS, Oxford Economic Papers, 54, 270-279.

Blackaby, D.H., Leslie, D.G., Murphy, P.D. and O'Leary, N.C. (2006) Born in Britain: How are Native Ethnic Minorities Faring in the British Labour Market?, Economic Letters, forthcoming.

Blinder, A.S. (1973) Wage discrimination: Reduced form and structural estimates, Journal of Human Resources, 8(4), 436-455.

Brown, C. and Gay, P. (1985) Racial discrimination: 17 years after the Act, London: Policy Studies Institute.

Chiswick, B. R. (1978) The Effect of Americanization on the Earnings of Foreign-Born Men, Journal of Political Economy, 86, 897-921.

Chiswick, B. R. (1980) The Earnings of White and Coloured Male Immigrants in Britain, Economica, 47, 81-87.

Coleman, D.A. and Salt, J. (1992) The British Population: Patterns, Trends and Processes, Oxford: Oxford University Press.

Connor, H. Tyers, C. Davis, S. and Tackey, N.D. (2003) Minority ethnic students in higher education: Interim Report, Brighton: The Institute of Employment Studies.

Constant, A. and Massey, D.S. (2003) Labor market Segmentation and the Earnings of Guest Workers, IZA Discussion Paper No. 774.

Dolton, P. and Vignoles, A. (2000) Incidence and Effects of Over Education in the UK Graduate Labour Market, Economics of Education Review, 19, 2, 179-198. 
Hartog, J. (2000) Over-education and Earnings: Where Are We, Where should we Go? Economics of Education Review, 19, 131-147.

Heckman, J. (1979) Sample Selection Bias as a Specification Error, Econometrica, 47, pp. 153- 61.

Heitmueller, A. (2003) Coordination Failure in Network Migration, IZA Discussion Paper No. 770.

Home Office (2005a) Controlling Our Borders: Making Migration Work for Britain, HM Government.

Home Office (2005b) Sizing the unauthorised (illegal) migrant population in the United Kingdom in 2001, HM Government, http://www.homeoffice.gov.uk/rds/pdfs05/rdsolr2905.pdf

Jones, F.L. (1983) On Decomposing the Wage Gap: A Critical Comment on Blinder's Method, Journal of Human Resources, 23, 279-295.

Lindley, J., Dale, A. and Dex, S. (2004) Ethnic differences in women's demographic and family characteristics and economic activity profiles 1992-2002 Labour Market Trends, April 2004.

Lindley, J. and Lenton, P. (2006) The over education of UK immigrants: Evidence from the Labour Force Survey, University of Sheffield, Department of Economics, Sheffield Economics Research Paper Series 2006001.

McIntosh, N and Smith, D. (1974) The extent of racial discrimination, London: Political and Economic Planning.

Neuman, S. and Silber, J.G., (1996) Wage Discrimination Across Ethnic Groups: Evidence from Israel, Economic Inquiry, vol. 34, pp. 648-61.

Oaxaca, R. (1973) Male-female wage differentials in urban labor markets, International Economic Review, 14, 693-709.

Oaxaca, R. and Ransom, M. R. (1994) On Discrimination and the Decomposition of Wage Differentials, Journal of Econometrics, 61, 5-21.

Pedersen, P.J., Pytlikova, M.M. and Smith, N. (2004) Selection or Network Effects? Migration Flows into 27 OECD Countries, 1990-2000, IZA Discussion Paper 1104.

Phelps, E. (1972) The statistical theory of racism and sexism, American Economic Review Vol 62.

Reed, D. and Chang, J. (2003) Racial and Ethnic Wage Gaps in the California Labor Market, Public Policy Institute of California Report.

Riach, P. and Rich, J. (1991) Testing for racial discrimination in the labour market, Cambridge Journal of Economics, vol. 15 pp.239-56.

Riach, P. and Rich, J. (1992) Measuring discrimination by direct experimental methods, seeking gunsmoke, Journal of Post Keynesian Economics, vol. 26, pp. 165-78 
Shields, M. and Wheatley Price, S. (1998) The Earnings of Male Immigrants in England: Evidence from the Quarterly LFS, Applied Economics, 30, 1157-1168.

Sloane, P, Battu, H. and Seaman, P. (1999) Over-education, Under-education and the British Labour Market, Applied Economics, 31, No 11, 1437-1454.

United Nations High Commissioner for Refugees (2001) Asylum Applications in Europe, http://www.unhcr.ch/statist/00asylall/00asylall.pdf

Yun, M, (2003) A Simple Solution to the Identification Problem in Detailed Wage Decompositions, IZA Discussion Paper no. 836. 
Table 1. Occupational Distribution by Immigrant Status (percent)

\begin{tabular}{|c|c|c|c|c|c|c|c|}
\hline & \multirow{2}{*}{ Full Sample } & \multicolumn{2}{|c|}{ Natives } & \multicolumn{4}{|c|}{ Immigrants $^{a}$} \\
\hline & & White & $\begin{array}{l}\text { Non- } \\
\text { white }\end{array}$ & White & $\begin{array}{l}\text { All Non- } \\
\text { white }\end{array}$ & Black & $\begin{array}{l}\text { South } \\
\text { Asian }\end{array}$ \\
\hline Professional occupations & 13 & 13 & 15 & 20 & 17 & 13 & 16 \\
\hline Managers and administrators & 20 & 20 & 18 & 23 & 12 & 9 & 12 \\
\hline $\begin{array}{l}\text { Associate prof \& tech } \\
\text { occupations }\end{array}$ & 11 & 11 & 14 & 11 & 8 & 10 & 5 \\
\hline Craft and related occupations & 17 & 18 & 12 & 10 & 12 & 10 & 13 \\
\hline Personal, protective occupations & 6 & 5 & 7 & 10 & 8 & 10 & 6 \\
\hline Sales occupations & 4 & 4 & 5 & 3 & 3 & 2 & 3 \\
\hline Plant and machine operatives & 16 & 16 & 12 & 10 & 19 & 21 & 25 \\
\hline Clerical, secretarial occupations & 7 & 7 & 12 & 5 & 8 & 7 & 9 \\
\hline Other occupations & 7 & 7 & 6 & 8 & 13 & 18 & 11 \\
\hline $\mathrm{N}$ & 151951 & 145276 & 1722 & 2588 & 2365 & 574 & 1098 \\
\hline
\end{tabular}

Source: QLFS 1992-2003 male full time workers (age 23-65). a Immigrants that arrived in the UK after they left full time education

Table 2. Mean Log Weekly Earnings by Occupation and Immigrant Status

\begin{tabular}{|c|c|c|c|c|c|c|c|}
\hline & Full & & ives & & Immig & ts ${ }^{a}$ & \\
\hline & & White & Non-white & White & $\begin{array}{l}\text { All Non- } \\
\text { whites }\end{array}$ & Black & $\begin{array}{l}\text { South } \\
\text { Asian }\end{array}$ \\
\hline \multirow{2}{*}{$\begin{array}{l}\text { Professional } \\
\text { occupations }\end{array}$} & 6.02 & 6.02 & $5.96^{*}$ & $6.10^{*}$ & $6.11^{*}$ & 6.05 & $6.18^{*}$ \\
\hline & [0.405] & $(0.003)$ & $(0.029)$ & $(0.020)$ & $(0.029)$ & $(0.066)$ & $(0.045)$ \\
\hline \multirow{2}{*}{$\begin{array}{l}\text { Managers and } \\
\text { administrators }\end{array}$} & 5.99 & 5.99 & $5.89^{*}$ & $6.08^{*}$ & $5.84 *$ & $5.82^{*}$ & $5.84^{*}$ \\
\hline & {$[0.472]$} & $(0.003)$ & $(0.027)$ & $(0.021)$ & $(0.037)$ & $(0.091)$ & $(0.052)$ \\
\hline \multirow{2}{*}{$\begin{array}{l}\text { Associate prof \& } \\
\text { tech occupations }\end{array}$} & 5.85 & 5.85 & $5.76^{*}$ & $6.01 *$ & $5.79 *$ & 5.78 & 5.77 \\
\hline & [0.414] & $(0.003)$ & $(0.027)$ & $(0.027)$ & $(0.026)$ & $(0.047)$ & $(0.050)$ \\
\hline \multirow{2}{*}{$\begin{array}{l}\text { Craft and related } \\
\text { occupations }\end{array}$} & 5.60 & 5.61 & 5.60 & 5.64 & $5.35^{*}$ & $5.44^{*}$ & $5.29 *$ \\
\hline & [0.401] & $(0.002)$ & $(0.027)$ & $(0.028)$ & $(0.034)$ & $(0.067)$ & (0.047) \\
\hline \multirow{4}{*}{$\begin{array}{l}\text { Personal, } \\
\text { protective } \\
\text { occupations } \\
\text { Sales occupations }\end{array}$} & 5.57 & 5.59 & $5.47^{*}$ & $5.47^{*}$ & $5.23^{*}$ & $5.39 *$ & $4.99 *$ \\
\hline & [0.474] & $(0.005)$ & $(0.042)$ & $(0.030)$ & (0.037) & $(0.058)$ & (0.077) \\
\hline & 5.57 & 5.58 & $5.47^{*}$ & 5.52 & $5.18^{*}$ & $5.18^{*}$ & $5.15^{*}$ \\
\hline & [0.488] & $(0.007)$ & $(0.059)$ & $(0.065)$ & $(0.058)$ & $(0.141)$ & (0.096) \\
\hline \multirow{2}{*}{$\begin{array}{l}\text { Plant and machine } \\
\text { operatives }\end{array}$} & 5.51 & 5.51 & $5.44^{*}$ & 5.54 & $5.36^{*}$ & $5.42 *$ & $5.33^{*}$ \\
\hline & [0.392] & $(0.003)$ & $(0.026)$ & $(0.025)$ & $(0.021)$ & $(0.029)$ & (0.028) \\
\hline \multirow{2}{*}{$\begin{array}{l}\text { Clerical, secretarial } \\
\text { occupations }\end{array}$} & 5.48 & 5.48 & $5.40^{*}$ & $5.60^{*}$ & 5.47 & 5.46 & 5.45 \\
\hline & [0.407] & $(0.004)$ & $(0.029)$ & $(0.038)$ & $(0.030)$ & $(0.074)$ & (0.037) \\
\hline \multirow[t]{2}{*}{ Other occupations } & 5.34 & 5.34 & $5.38^{*}$ & 5.32 & $5.26^{*}$ & 5.31 & $5.20^{*}$ \\
\hline & [0.393] & $(0.004)$ & $(0.039)$ & $(0.032)$ & $(0.027)$ & $(0.044)$ & $(0.045)$ \\
\hline \multirow[t]{2}{*}{ Total } & 5.72 & 5.72 & $5.66^{*}$ & $5.81^{*}$ & $5.56^{*}$ & $5.55^{*}$ & 5.52 \\
\hline & [0.484] & (0001) & $(0.012)$ & $(0.011)$ & $(0.012)$ & $(0.021)$ & $(0.019)$ \\
\hline $\mathrm{N}$ & 151951 & 145276 & 1722 & 2588 & 2365 & 574 & 1098 \\
\hline
\end{tabular}

Source: QLFS 1992-2003 male full time workers (age 23-65). Standard errors in parentheses and standard deviations in square brackets. $a$ Immigrants that arrived in the UK after they left full time education. * Difference to white natives is significantly different from zero at the 5 percent level. 
Table 3. Key Results with Marginal Effects for Multinomial Logit for Occupational Attainment for Natives and Immigrants.

\begin{tabular}{|c|c|c|c|}
\hline & Professionals & Managers & Assoc Profs \\
\hline British Born South Asian & $-0.021(0.009)$ & $-0.035(0.019)$ & $-0.031(0.011)$ \\
\hline British Born Black & $-0.043(0.008)$ & $-0.062(0.015)$ & $-0.007(0.012)$ \\
\hline British Born Other non/white & $-0.013(0.013)$ & $-0.027(0.023)$ & $0.013(0.017)$ \\
\hline Immigrant White & $-0.037(0.007)$ & $-0.209(0.019)$ & $-0.020(0.012)$ \\
\hline Immigrant South Asian & $-0.081(0.005)$ & $-0.198(0.009)$ & $-0.108(0.005)$ \\
\hline Immigrant Black & $-0.083(0.005)$ & $-0.205(0.008)$ & $-0.081(0.009)$ \\
\hline Immigrant Other non/white & $-0.065(0.009)$ & $-0.145(0.017)$ & $-0.064(0.012)$ \\
\hline Years since migration (YSM) & $-0.005(0.002)$ & $-0.005(0.004)$ & $-0.002(0.003)$ \\
\hline YSM Squared (YSM Sq) & $0.00012(0.0002)$ & $0.0001(0.0001)$ & $0.0001(0.0001)$ \\
\hline YSM * Immigrant White & $0.007(0.003)$ & $0.004(0.005)$ & $0.003(0.003)$ \\
\hline YSM Sq * Immigrant White & $-0.0002(0.0001)$ & $-0.0001(0.0001)$ & $-0.0001(0.0001)$ \\
\hline Schooling & $0.107(0.003)$ & $0.198(0.006)$ & $0.096(0.004)$ \\
\hline \multirow[t]{2}{*}{ Schooling Squared } & $-0.002(0.0001)$ & $-0.005(0.0002)$ & $-0.002(0.0001)$ \\
\hline & Craft & Personal/Prot & Sales \\
\hline British Born South Asian & $-0.033(0.018)$ & $-0.013(0.007)$ & $0.017(0.009)$ \\
\hline British Born Black & $0.037(0.017)$ & $0.021(0.008)$ & $-0.012(0.006)$ \\
\hline British Born Other non/white & $-0.052(0.019)$ & $0.037(0.013)$ & $0.016(0.011)$ \\
\hline Immigrant White & $0.001(0.021)$ & $0.067(0.013)$ & $-0.006(0.007)$ \\
\hline Immigrant South Asian & $-0.014(0.024)$ & $0.014(0.012)$ & $-0.022(0.006)$ \\
\hline Immigrant Black & $-0.039(0.024)$ & $0.036(0.016)$ & $-0.029(0.004)$ \\
\hline Immigrant Other non/white & $-0.003(0.027)$ & $0.089(0.023)$ & $-0.005(0.010)$ \\
\hline Years since migration (YSM) & $0.005(0.003)$ & $-0.0001(0.001)$ & $0.002(0.001)$ \\
\hline YSM Squared (YSM Sq) & $-0.0001(0.0001)$ & $-0.00001(0.00003)$ & $-0.00003(0.00004)$ \\
\hline YSM* Immigrant White & $-0.004(0.004)$ & $-0.0002(0.001)$ & $-0.004(0.002)$ \\
\hline YSM Sq * Immigrant White & $0.00001(0.0001)$ & $0.00003(0.00003)$ & $0.0001(0.00005)$ \\
\hline Schooling & $-0.166(0.005)$ & $-0.020(0.002)$ & $0.006(0.003)$ \\
\hline \multirow[t]{2}{*}{ Schooling Squared } & $0.004(0.0002)$ & $0.0004(0.0001)$ & $0.0002(0.0001)$ \\
\hline & Plant/ Machine & Clerical & Other Occupation \\
\hline British Born South Asian & $0.069(0.023)$ & $0.035(0.04)$ & $0.013(0.015)$ \\
\hline British Born Black & $0.012(0.014)$ & $0.037(0.012)$ & $0.018(0.011)$ \\
\hline British Born Other non/white & $0.020(0.022)$ & $0.031(0.016)$ & $-0.026(0.010)$ \\
\hline Immigrant White & $-0.014(0.018)$ & $-0.018(0.009)$ & $0.056(0.017)$ \\
\hline Immigrant South Asian & $0.245(0.039)$ & $-0.035(0.01)$ & $0.200(0.035)$ \\
\hline Immigrant Black & $0.165(0.038)$ & $-0.044(0.008)$ & $0.284(0.041)$ \\
\hline Immigrant Other non/white & $0.038(0.027)$ & $-0.027(0.012)$ & $0.167(0.032)$ \\
\hline Years since migration (YSM) & $-0.001(0.002)$ & $0.007(0.002)$ & $-0.001(0.001)$ \\
\hline YSM Squared (YSM Sq) & $0.0001(0.0001)$ & $-0.0002(0.0001)$ & $-0.00003(0.00003)$ \\
\hline YSM* Immigrant White & $0.0015(0.003)$ & $-0.007(0.003)$ & $-0.002(0.002)$ \\
\hline YSM Sq * Immigrant White & $5.10 \mathrm{e}-07(0.0001)$ & $0.0002(0.0001)$ & $0.00001(0.00004)$ \\
\hline Schooling & $-0.161(0.004)$ & $0.019(0.004)$ & $-0.079(0.002)$ \\
\hline Schooling Squared & $0.004(0.0002)$ & $-0.006(0.0001)$ & $0.002(0.0001)$ \\
\hline
\end{tabular}

Notes: Standard Errors in parentheses. 
Table 4. Key Results for Single Equation Within-Occupational Ethnic-Immigrant Earnings Equations.

\begin{tabular}{|c|c|c|c|c|c|c|c|c|c|c|}
\hline & All & Professionals & Managers & Assoc Prof & Craft & Personal/Prot & Sales & Plant \& Machine & Clerical & Other \\
\hline British Born S Asian & $\begin{array}{l}-0.120 \\
(0.018)^{* *}\end{array}$ & $\begin{array}{l}0.023 \\
(0.034)\end{array}$ & $\begin{array}{l}-0.075 \\
(0.039)\end{array}$ & $\begin{array}{l}-0.038 \\
(0.043)\end{array}$ & $\begin{array}{l}-0.140 \\
(0.055)^{*}\end{array}$ & $\begin{array}{l}-0.162 \\
(0.098)\end{array}$ & $\begin{array}{l}-0.253 \\
(0.072)^{* *}\end{array}$ & $\begin{array}{l}-0.144 \\
(0.045)^{* *}\end{array}$ & $\begin{array}{l}-0.131 \\
(0.044)^{* *}\end{array}$ & $\begin{array}{l}0.041 \\
(0.072)\end{array}$ \\
\hline British Born Black & $\begin{array}{l}-0.103 \\
(0.015)^{* *}\end{array}$ & $\begin{array}{l}-0.063 \\
(0.043)\end{array}$ & $\begin{array}{l}-0.078 \\
(0.038)^{*}\end{array}$ & $\begin{array}{l}-0.165 \\
(0.038)^{* *}\end{array}$ & $\begin{array}{l}-0.025 \\
(0.034)\end{array}$ & $\begin{array}{l}0.027 \\
(0.050)\end{array}$ & $\begin{array}{l}0.118 \\
(0.092)\end{array}$ & $\begin{array}{l}-0.095 \\
(0.039)^{*}\end{array}$ & $\begin{array}{l}-0.090 \\
(0.038)^{*}\end{array}$ & $\begin{array}{l}-0.008 \\
(0.047)\end{array}$ \\
\hline British Born Oth $\mathrm{n} /$ white & $\begin{array}{l}-0.046 \\
(0.021)^{*}\end{array}$ & $\begin{array}{l}-0.033 \\
(0.048)\end{array}$ & $\begin{array}{l}-0.031 \\
(0.049)\end{array}$ & $\begin{array}{l}-0.028 \\
(0.047)\end{array}$ & $\begin{array}{l}-0.043 \\
(0.068)\end{array}$ & $\begin{array}{l}-0.196 \\
(0.065)^{* *}\end{array}$ & $\begin{array}{l}0.067 \\
(0.092)\end{array}$ & $\begin{array}{l}-0.011 \\
(0.056)\end{array}$ & $\begin{array}{l}-0.003 \\
(0.055)\end{array}$ & $\begin{array}{l}0.098 \\
(0.097)\end{array}$ \\
\hline Immigrant White & $\begin{array}{c}0.019 \\
(0.016)\end{array}$ & $\begin{array}{l}0.049 \\
(0.029)\end{array}$ & $\begin{array}{l}0.143 \\
(0.034)^{* *}\end{array}$ & $\begin{array}{l}0.152 \\
(0.039)^{*}\end{array}$ & $\begin{array}{l}-0.014 \\
(0.053)\end{array}$ & $\begin{array}{l}-0.048 \\
(0.043)\end{array}$ & $\begin{array}{l}-0.159 \\
(0.099)\end{array}$ & $\begin{array}{l}0.024 \\
(0.06)\end{array}$ & $\begin{array}{l}0.048 \\
(0.056)\end{array}$ & $\begin{array}{l}-0.129 \\
(0.053)^{* *}\end{array}$ \\
\hline Immigrant $\mathrm{S}$ Asian & $\begin{array}{l}-0.393 \\
(0.023)^{* *}\end{array}$ & $\begin{array}{l}0.038 \\
(0.044)\end{array}$ & $\begin{array}{l}-0.124 \\
(0.072)^{* *}\end{array}$ & $\begin{array}{l}-0.234 \\
(0.078)^{*}\end{array}$ & $\begin{array}{l}-0.679 \\
(0.072)^{* *}\end{array}$ & $\begin{array}{l}-0.499 \\
(0.082)^{* *}\end{array}$ & $\begin{array}{l}-0.604 \\
(0.151)^{* *}\end{array}$ & $\begin{array}{l}-0.395 \\
(0.051)^{* *}\end{array}$ & $\begin{array}{l}-0.157 \\
(0.078)^{*}\end{array}$ & $\begin{array}{l}-0.392 \\
(0.056)^{* *}\end{array}$ \\
\hline Immigrant Black & $\begin{array}{l}-0.348 \\
(0.025)^{* *}\end{array}$ & $\begin{array}{l}-0.124 \\
(0.057) *\end{array}$ & $\begin{array}{l}-0.125 \\
(0.129)\end{array}$ & $\begin{array}{l}-0.221 \\
(0.072)^{*}\end{array}$ & $\begin{array}{l}-0.577 \\
(0.080)^{* *}\end{array}$ & $\begin{array}{l}-0.156 \\
(0.074)^{*}\end{array}$ & $\begin{array}{l}-0.703 \\
(0.165)^{* *}\end{array}$ & $\begin{array}{l}-0.306 \\
(0.055)^{* *}\end{array}$ & $\begin{array}{l}-0.131 \\
(0.082)\end{array}$ & $\begin{array}{l}-0.257 \\
(0.054)^{* *}\end{array}$ \\
\hline Immigrant Other $\mathrm{n} /$ white & $\begin{array}{l}-0.283 \\
(0.023)^{* *}\end{array}$ & $\begin{array}{l}-0.109 \\
(0.045)^{*}\end{array}$ & $\begin{array}{l}-0.129 \\
(0.061)^{* *}\end{array}$ & $\begin{array}{l}-0.146 \\
(0.064)^{*}\end{array}$ & $\begin{array}{l}-0.552 \\
(0.070)^{* *}\end{array}$ & $\begin{array}{l}-0.264 \\
(0.077)^{*}\end{array}$ & $\begin{array}{l}-0.512 \\
(0.138)^{* *}\end{array}$ & $\begin{array}{l}-0.322 \\
(0.060)^{* *}\end{array}$ & $\begin{array}{l}-0.068 \\
(0.076)\end{array}$ & $\begin{array}{l}-0.248 \\
(0.060)^{* *}\end{array}$ \\
\hline Years since migration & $\begin{array}{l}-0.011 \\
(0.003)^{* *}\end{array}$ & $\begin{array}{l}0.0157 \\
(0.006)^{*}\end{array}$ & $\begin{array}{l}-0.027 \\
(0.008)^{* *}\end{array}$ & $\begin{array}{l}-0.003 \\
(0.008)\end{array}$ & $\begin{array}{l}0.017 \\
(0.007)\end{array}$ & $\begin{array}{l}-0.019 \\
(0.009)^{*}\end{array}$ & $\begin{array}{l}-0.013 \\
(0.018)\end{array}$ & $\begin{array}{l}0.002 \\
(0.006)\end{array}$ & $\begin{array}{l}-0.027 \\
(0.009)^{* *}\end{array}$ & $\begin{array}{l}0.014 \\
(0.006)^{*}\end{array}$ \\
\hline YSM Squared & $\begin{array}{l}0.0004 \\
(0.0001)^{* *}\end{array}$ & $\begin{array}{l}-0.001 \\
(0.0002) *\end{array}$ & $\begin{array}{l}0.0005 \\
(0.0002) * *\end{array}$ & $\begin{array}{l}0.0001 \\
(0.0002)\end{array}$ & $\begin{array}{l}-0.00012 \\
(0.0002)\end{array}$ & $\begin{array}{l}0.0006 \\
(0.0002)^{*}\end{array}$ & $\begin{array}{l}0.0007 \\
(0.0005)\end{array}$ & $\begin{array}{l}-0.00019 \\
(0.00013)\end{array}$ & $\begin{array}{l}0.0009 \\
(0.00025)^{* *}\end{array}$ & $\begin{array}{l}-0.00015 \\
(0.0002)\end{array}$ \\
\hline YSM* Immigrant White & $\begin{array}{l}0.006 \\
(0.004)\end{array}$ & $\begin{array}{l}-0.017 \\
(0.008)^{*}\end{array}$ & $\begin{array}{l}0.009 \\
(0.009)\end{array}$ & $\begin{array}{l}-0.009 \\
(0.01)\end{array}$ & $\begin{array}{l}-0.025 \\
(0.010)^{*}\end{array}$ & $\begin{array}{l}0.010 \\
(0.012)\end{array}$ & $\begin{array}{l}0.024 \\
(0.023)\end{array}$ & $\begin{array}{l}0.002 \\
(0.009)\end{array}$ & $\begin{array}{l}0.045 \\
(0.013)^{* *}\end{array}$ & $\begin{array}{l}-0.015 \\
(0.009)\end{array}$ \\
\hline $\begin{array}{l}\text { YSM Sq * Immigrant } \\
\text { White }\end{array}$ & -0.0003 & 0.0005 & -0.0003 & 0.0002 & 0.0003 & -0.0003 & -0.0008 & -0.0003 & -0.001 & 0.0003 \\
\hline & $(0.0001)^{* *}$ & $(0.0002)^{*}$ & $(0.0002)$ & $(0.0003)$ & $(0.0002)$ & $(0.0003)$ & $(0.0006)$ & $(0.0002)$ & $(0.0003)^{* *}$ & $(0.0002)$ \\
\hline Schooling & $\begin{array}{l}0.189 \\
(0.003)^{* *}\end{array}$ & $\begin{array}{l}0.123 \\
(0.007)^{* *}\end{array}$ & $\begin{array}{l}0.212 \\
(0.010)^{* *}\end{array}$ & $\begin{array}{l}0.137 \\
(0.011)^{* *}\end{array}$ & $\begin{array}{l}0.039 \\
(0.009)^{* *}\end{array}$ & $\begin{array}{l}0.174 \\
(0.017)^{* *}\end{array}$ & $\begin{array}{l}0.107 \\
(0.016)^{* *}\end{array}$ & $\begin{array}{l}0.018 \\
(0.010)\end{array}$ & $\begin{array}{l}0.097 \\
(0.009)^{* *}\end{array}$ & $\begin{array}{l}0.085 \\
(0.018)^{* *}\end{array}$ \\
\hline Schooling Squared & $\begin{array}{l}-0.004 \\
(0.0001)^{* *}\end{array}$ & $\begin{array}{l}-0.003 \\
(0.0002)^{* *}\end{array}$ & $\begin{array}{l}-0.005 \\
(0.0003) * *\end{array}$ & $\begin{array}{l}-0.004 \\
(0.0004)^{* *}\end{array}$ & $\begin{array}{l}-0.0003 \\
(0.0003)\end{array}$ & $\begin{array}{l}-0.004 \\
(0.001)^{* *}\end{array}$ & $\begin{array}{l}-0.002 \\
(0.001)^{* *}\end{array}$ & $\begin{array}{l}-0.000041 \\
(0.00037)\end{array}$ & $\begin{array}{l}-0.002 \\
(0.0003)^{* *}\end{array}$ & $\begin{array}{l}-0.003 \\
(0.001)^{* *}\end{array}$ \\
\hline Observations & 151951 & 19897 & 30824 & 16217 & 26539 & 8535 & 5334 & 23478 & 10463 & 10664 \\
\hline R-squared & 0.25 & 0.18 & 0.22 & 0.17 & 0.11 & 0.32 & 0.20 & 0.12 & 0.21 & 0.15 \\
\hline
\end{tabular}

Notes: Standard Errors in parentheses and * denotes significant at 5\%; ** denotes significant at $1 \%$. 
Table 5. Key results for separate occupation immigrant/native ethnic pay differentials.

\begin{tabular}{|c|c|c|c|c|}
\hline & Natives. & Immigrants, OLS. & $\begin{array}{l}\text { Immigrants, } \\
\text { Heckman. }\end{array}$ & $\begin{array}{l}\text { Occupation Selection } \\
\text { Equation a }\end{array}$ \\
\hline \multicolumn{5}{|l|}{ All } \\
\hline Black & $-0.103(0.015)^{* *}$ & $-0.360(0.025)^{* *}$ & - & - \\
\hline South Asian & $-0.120(0.017)^{* *}$ & $-0.396(0.020)^{* *}$ & - & - \\
\hline Other Non-white & $-0.046(0.021)^{*}$ & $-0.258(0.022)^{* *}$ & - & - \\
\hline Schooling & $0.208(0.004)^{* *}$ & $0.066(0.011)^{* *}$ & - & - \\
\hline Schooling Sq & $-0.005(0.0001)^{* *}$ & $-0.000(0.0003)$ & - & - \\
\hline Rho ${ }^{b}$ & - & - & - & - \\
\hline Observations & 146998 & 4953 & - & - \\
\hline \multicolumn{5}{|l|}{ Professionals } \\
\hline Black & $-0.065(0.042)$ & $-0.119(0.064)^{*}$ & $-0.124(0.070)^{*}$ & $-0.268(0.084)^{* *}$ \\
\hline South Asian & $0.025(0.034)$ & $-0.006(0.047)$ & $-0.010(0.054)$ & $-0.272(0.065)^{* *}$ \\
\hline Other Non-white & $-0.034(0.047)$ & $-0.104(0.048)^{* *}$ & $-0.105(0.048)^{* *}$ & $-0.090(0.071)$ \\
\hline Schooling & $0.125(0.007)^{* *}$ & $0.127(0.036)^{* *}$ & $0.135(0.061)^{* *}$ & $0.328(0.054)^{* *}$ \\
\hline Schooling Sq & $-0.003(0.000)^{* *}$ & $-0.003(0.001)^{* *}$ & $-0.003(0.001)^{* *}$ & $-0.004(0.002)^{* *}$ \\
\hline Arrived 1971-1987 & - & - & - & $-0.135(0.094)$ \\
\hline Arrived 1988-1992 & - & - & - & $-0.292(0.116)^{*}$ \\
\hline Arrived 1993-1998 & - & - & - & $-0.304(0.129)^{*}$ \\
\hline Arrived after 1999 & - & - & - & $-0.194(0.154)$ \\
\hline Rho $^{b}$ & - & - & - & $0.298(0.316)$ \\
\hline Observations & 18995 & 902 & 4953 & 4953 \\
\hline \multicolumn{5}{|l|}{ Managers } \\
\hline Black & $-0.078(0.037)^{* *}$ & $-0.323(0.077)^{* *}$ & $-0.331(0.116)^{* *}$ & $-0.699(0.082)^{* *}$ \\
\hline South Asian & $-0.076(0.039)^{*}$ & $-0.298(0.054)^{* *}$ & $-0.304(0.089)^{* *}$ & $-0.582(0.062) * *$ \\
\hline Other Non-white & $-0.032(0.049)$ & $-0.303(0.054) * *$ & $-0.308(0.072)^{* *}$ & $-0.403(0.067)^{* *}$ \\
\hline Schooling & $0.222(0.010)^{* *}$ & $0.058(0.042)$ & $0.064(0.070)$ & $0.453(0.050)^{* *}$ \\
\hline Schooling Sq & $-0.006(0.0001)^{* *}$ & $-0.001(0.001)$ & $-0.001(0.002)$ & $-0.013(0.002)^{* *}$ \\
\hline Arrived 1971-1987 & - & - & - & $0.073(0.081)$ \\
\hline Arrived 1988-1992 & - & - & - & $0.087(0.103)$ \\
\hline Arrived 1993-1998 & - & - & - & $0.134(0.112)$ \\
\hline Arrived after 1999 & - & - & - & $0.183(0.143)$ \\
\hline Rho b & - & - & - & $0.048(0.305)$ \\
\hline Observations & 29950 & 874 & 4953 & 4953 \\
\hline \multicolumn{5}{|l|}{ Assoc Prof } \\
\hline Black & $-0.164(0.038)^{* *}$ & $-0.280(0.065)^{* *}$ & $-0.277(0.074)^{* *}$ & $-0.052(0.081)$ \\
\hline South Asian & $-0.038(0.043)$ & $-0.273(0.065)^{* *}$ & $-0.064(0.075)$ & $-0.428(0.076)^{* *}$ \\
\hline Other Non-white & $-0.028(0.047)$ & $-0.189(0.057)^{* *}$ & $-0.181(0.065)^{* *}$ & $-0.086(0.074)$ \\
\hline Schooling & $0.141(0.012)^{* *}$ & $0.027(0.062)$ & $-0.218(0.071)^{* *}$ & $0.490(0.066)^{* *}$ \\
\hline Schooling Sq & $-0.004(0.000)^{* *}$ & $-0.0001(0.002)$ & $0.006(0.002)^{* *}$ & $-0.014(0.002)^{* *}$ \\
\hline Arrived 1971-1987 & - & - & - & $-0.155(0.087)^{*}$ \\
\hline Arrived 1988-1992 & - & - & - & $-0.146(0.109)$ \\
\hline Arrived 1993-1998 & - & - & - & $-0.120(0.117)$ \\
\hline Arrived after 1999 & - & - & - & $-0.068(0.152)$ \\
\hline Rho $^{b}$ & - & - & - & $-1.52(0.139)^{* * *}$ \\
\hline Observations & 15727 & 490 & 4953 & 4953 \\
\hline \multicolumn{5}{|l|}{ Craft and Related } \\
\hline Black & $-0.023(0.034)$ & $-0.430(0.074)^{* *}$ & $-0.421(0.074)^{* *}$ & $0.030(0.083)$ \\
\hline South Asian & $-0.142(0.054)^{* *}$ & $-0.424(0.058)^{* *}$ & $-0.386(0.063)^{* *}$ & $0.191(0.066)^{* *}$ \\
\hline Other Non-white & $-0.042(0.068)$ & $-0.295(0.064)^{* *}$ & $-0.278(0.064)^{* *}$ & $0.092(0.078)$ \\
\hline Schooling & $0.031(0.009)^{* *}$ & $0.130(0.045)^{* *}$ & $0.139(0.044)^{* *}$ & $0.034(0.046)$ \\
\hline Schooling Sq & $0.0001(0.0001)$ & $-0.004(0.002)^{*}$ & $-0.005(0.002) * *$ & $-0.005(0.002)^{* *}$ \\
\hline Arrived 1971-1987 & - & - & - & $-0.121(0.088)$ \\
\hline Arrived 1988-1992 & - & - & - & $-0.075(0.116)$ \\
\hline Arrived 1993-1998 & - & - & - & $-0.249(0.129)^{*}$ \\
\hline
\end{tabular}




\begin{tabular}{|c|c|c|c|c|}
\hline Arrived after 1999 & - & - & - & $-0.484(0.178)^{* *}$ \\
\hline Rho b & - & - & - & $0.512(0.332)$ \\
\hline \multirow{2}{*}{$\begin{array}{l}\text { Observations } \\
\text { Pers/Protection }\end{array}$} & 26004 & 535 & 4953 & 4953 \\
\hline & & & & \\
\hline Black & 0.027 (0.049) & $-0.302(0.076)^{* *}$ & $-0.300(0.074)^{* *}$ & $0.040(0.084)$ \\
\hline South Asian & $-0.161(0.097)$ & $-0.518(0.067)^{* *}$ & $-0.538(0.073)^{* *}$ & $-0.206(0.077)^{* *}$ \\
\hline Other Non-white & $-0.196(0.065)^{* *}$ & $-0.221(0.058)^{* *}$ & $-0.206(0.062)^{* *}$ & $0.154(0.076)^{*}$ \\
\hline Schooling & $0.224(0.022)^{* *}$ & $0.052(0.032)$ & $0.050(0.031)$ & $-0.035(0.039)$ \\
\hline Schooling Sq & $-0.006(0.001)^{* *}$ & $-0.001(0.001)$ & $-0.001(0.001)$ & $-0.002(0.001)$ \\
\hline Arrived 1971-1987 & - & - & - & $0.300(0.094) * *$ \\
\hline Arrived 1988-1992 & - & - & - & $0.449(0.118) * *$ \\
\hline Arrived 1993-1998 & - & - & - & $0.399(0.132)^{* *}$ \\
\hline Arrived after 1999 & - & - & - & $0.032(0.215)$ \\
\hline $\mathrm{Rho}^{\mathrm{b}}$ & - & - & - & $0.289(0.464)$ \\
\hline Observations & 8075 & 460 & 4953 & 4953 \\
\hline \multicolumn{5}{|l|}{ Plant \& Machine } \\
\hline Black & $-0.093(0.039)^{*}$ & $-0.190(0.051)^{* *}$ & $-0.100(0.068)$ & $0.523(0.074)^{* *}$ \\
\hline South Asian & $-0.145(0.045)^{* *}$ & $-0.262(0.042)^{* *}$ & $-0.149(0.070)^{*}$ & $0.670(0.062)^{* *}$ \\
\hline Other Non-white & $-0.009(0.056)$ & $-0.198(0.059)^{* *}$ & $-0.191(0.059)^{* *}$ & $0.067(0.082)$ \\
\hline Schooling & $0.034(0.016)^{*}$ & $0.004(0.014)$ & $-0.006(0.016)$ & $-0.093(0.042)^{*}$ \\
\hline Schooling Sq & $-0.001(0.001)$ & $0.0001(0.001)$ & $-0.0001(0.001)$ & $-0.001(0.001)$ \\
\hline Arrived 1971-1987 & - & - & - & $-0.182(0.080)^{*}$ \\
\hline Arrived 1988-1992 & - & - & - & $-0.242(0.109)^{*}$ \\
\hline Arrived 1993-1998 & - & - & - & $-0.217(0.120)^{*}$ \\
\hline Arrived after 1999 & - & - & - & $-0.165(0.164)$ \\
\hline Rho ${ }^{b}$ & - & - & - & $0.623(0.316)^{*}$ \\
\hline Observations & 22763 & 715 & 4953 & 4953 \\
\hline Clerical & & & & \\
\hline Black & $-0.091(0.038)^{*}$ & $-0.269(0.082)^{* *}$ & $-0.335(0.088)^{* *}$ & $0.136(0.091)$ \\
\hline South Asian & $-0.132(0.044)^{* *}$ & $-0.330(0.067)^{* *}$ & $-0.507(0.079)^{* *}$ & $0.315(0.074)^{* *}$ \\
\hline Other Non-white & $-0.003(0.055)$ & $-0.235(0.073)^{* *}$ & $-0.317(0.081)^{* *}$ & $0.178(0.084)^{*}$ \\
\hline Schooling & $0.097(0.010)^{* *}$ & $0.060(0.047)$ & $-0.042(0.054)$ & $0.227(0.061)^{* *}$ \\
\hline Schooling Sq & $-0.002(0.000)^{* *}$ & $-0.001(0.001)$ & $0.002(0.002)$ & $-0.007(0.002)^{* *}$ \\
\hline Arrived 1971-1987 & - & - & - & $-0.087(0.092)$ \\
\hline Arrived 1988-1992 & - & - & - & $-0.113(0.121)$ \\
\hline Arrived 1993-1998 & - & - & - & $-0.025(0.133)$ \\
\hline Arrived after 1999 & - & - & - & $-0.090(0.182)$ \\
\hline Rho $^{b}$ & - & - & - & $-1.35(0.189)^{* * *}$ \\
\hline Observations & 10132 & 331 & 4953 & 4953 \\
\hline Other \& Sales & & & & \\
\hline Black & $-0.013(0.045)$ & $-0.193(0.057)^{* *}$ & $-0.361(0.070)^{* *}$ & $0.425(0.071)^{* *}$ \\
\hline South Asian & $-0.129(0.051)^{* *}$ & $-0.285(0.052)^{* *}$ & $-0.393(0.059) * *$ & $0.300(0.063)^{* *}$ \\
\hline Other Non-white & $0.112(0.067)^{*}$ & $-0.151(0.055)^{* *}$ & $-0.255(0.063) * *$ & $0.245(0.071)^{* *}$ \\
\hline Schooling & $0.125(0.012)^{* *}$ & $0.140(0.034)^{* *}$ & $0.142(0.035)^{* *}$ & $0.003(0.036)$ \\
\hline Schooling Sq & $-0.003(0.0001)^{* *}$ & $-0.004(0.001)^{* *}$ & $-0.003(0.001)^{* *}$ & $-0.003(0.001)^{* *}$ \\
\hline Arrived 1971-1987 & - & - & - & $0.169(0.082)^{*}$ \\
\hline Arrived 1988-1992 & - & - & - & $0.266(0.104)^{*}$ \\
\hline Arrived 1993-1998 & - & - & - & $0.197(0.114)$ \\
\hline Arrived after 1999 & - & - & - & $0.254(0.148)$ \\
\hline Rho $^{b}$ & - & - & - & $-1.087(0.189)^{* *}$ \\
\hline Observations & 15352 & 646 & 4953 & 4953 \\
\hline $\begin{array}{l}\text { Standard Err } \\
\text { a. These are } \\
\text { variable is ec } \\
\text { immigration } \\
\text { Other contro }\end{array}$ & $\begin{array}{l}\text { s in parentheses and } * d \\
\text { oefficients from probit } \\
\text { al to } 1 \text { if employed it } \\
\text { licy in } 1971,1988,199 \\
\text { are the same as those fo }\end{array}$ & $\begin{array}{l}\text { es significant at } 5 \% \text {; } \\
\text { ction equations estim } \\
\text { relevant occupation } \\
1999 \text { at year of arri } \\
\text { immigrant earnings e }\end{array}$ & $\begin{array}{l}\text { otes significant at } 1 \% \text {. } \\
\text { on a sample of immi } \\
\text { zero otherwise, four } \\
\text { e used as instruments } \\
\text { on. }\end{array}$ & $\begin{array}{l}\text { ts only. Where the dependent } \\
\text { nmy variables for changes in } \\
\text { dentify the earnings equations. }\end{array}$ \\
\hline b Rho prov & the correlation betw & error term in the $\mathrm{e}$ & $s$ equation and the e & term in the occupation probit \\
\hline
\end{tabular}


Table 6. Mean Log Nominal Gross Weekly Earnings Decompositions (White Natives are the base category).

(a) Without Occupation Controls.

\begin{tabular}{|c|c|c|c|c|c|}
\hline & $\begin{array}{c}\text { Non-White } \\
\text { Natives }\end{array}$ & $\begin{array}{c}\text { White } \\
\text { Immigrants }\end{array}$ & $\begin{array}{l}\text { Non-White } \\
\text { Immigrants }\end{array}$ & $\begin{array}{c}\text { Black } \\
\text { Immigrants }\end{array}$ & $\begin{array}{l}\text { South Asian } \\
\text { Immigrants }\end{array}$ \\
\hline Total Differential & 0.064 & -0.092 & 0.162 & 0.171 & 0.204 \\
\hline Coefficient & 0.094 & 0.014 & 0.344 & 0.323 & 0.396 \\
\hline Characteristic & -0.030 & -0.107 & -0.183 & -0.152 & -0.192 \\
\hline \multicolumn{6}{|c|}{ Characteristic Components } \\
\hline Age & 0.054 & 0.014 & -0.008 & -0.001 & $-0.012-y$ \\
\hline Schooling & -0.104 & -0.098 & -0.121 & -0.096 & -0.117 \\
\hline Year & -0.007 & -0.002 & -0.002 & -0.003 & 0.000 \\
\hline Married & 0.034 & 0.001 & -0.019 & -0.005 & -0.031 \\
\hline Region & -0.050 & -0.056 & -0.061 & -0.082 & -0.048 \\
\hline Sector & 0.010 & 0.007 & 0.009 & 0.011 & 0.005 \\
\hline Tenure & 0.033 & 0.027 & 0.020 & 0.024 & 0.012 \\
\hline $\mathrm{N}^{\mathrm{a}}$ & 1722 & 2588 & 2365 & 574 & 1098 \\
\hline
\end{tabular}

(b) With Occupation Controls.

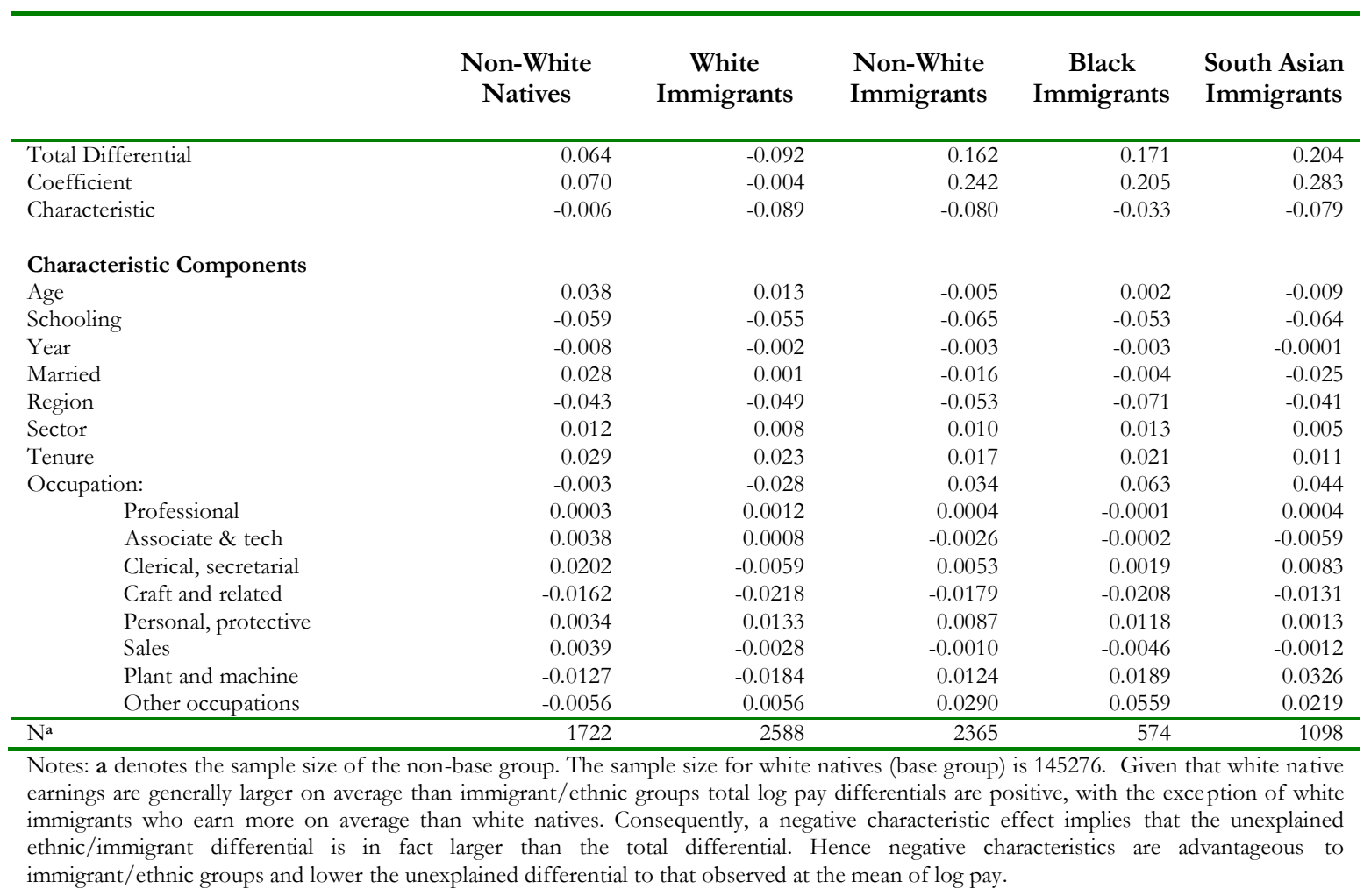


Table 7. Immigrant Mean Log Nominal Gross Weekly Earnings Decompositions

(White Immigrants are the base category)

(a) Without Occupation Controls.

\begin{tabular}{|c|c|c|c|}
\hline & Non-White Immigrants & Black Immigrants & South Asian Immigrants \\
\hline Total Differential & 0.254 & 0.264 & 0.296 \\
\hline Coefficient & 0.278 & 0.287 & 0.305 \\
\hline Characteristic & -0.024 & -0.023 & -0.009 \\
\hline \multicolumn{4}{|l|}{ Characteristic Components } \\
\hline Age & -0.019 & -0.008 & -0.028 \\
\hline Schooling & -0.016 & 0.004 & -0.015 \\
\hline Year & 0.000 & -0.001 & 0.001 \\
\hline Married & 0.008 & -0.003 & 0.018 \\
\hline Region & 0.006 & -0.015 & 0.027 \\
\hline Sector & 0.015 & 0.014 & 0.016 \\
\hline Tenure & -0.012 & -0.005 & -0.023 \\
\hline Immigrant Arrival Cohort & 0.006 & 0.004 & 0.021 \\
\hline English speaking country of origin & -0.010 & -0.014 & -0.026 \\
\hline $\mathrm{N}^{\mathrm{a}}$ & 2365 & 574 & 1098 \\
\hline
\end{tabular}

(b) With Occupation Controls.

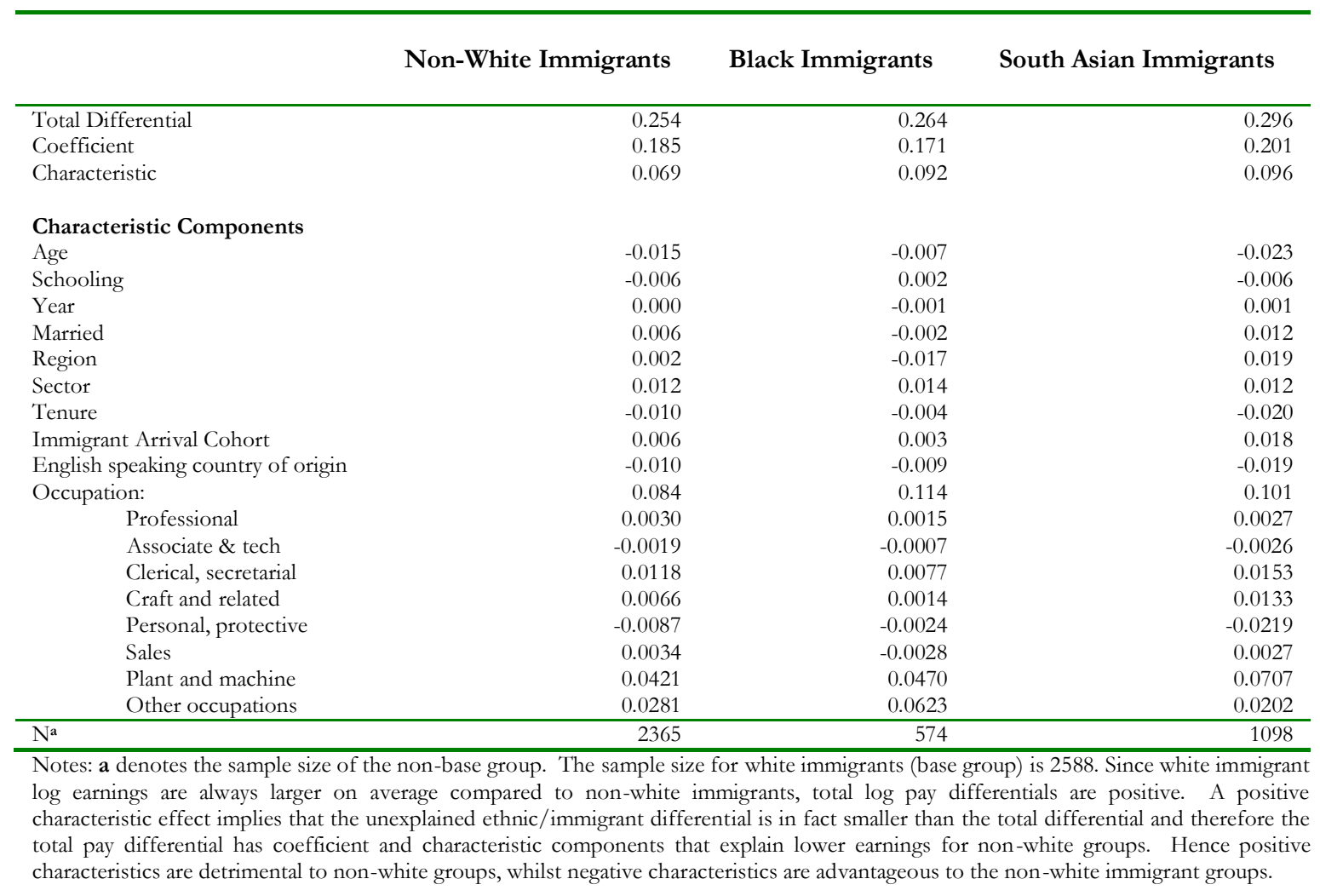


Table 8. Mean Log Nominal Gross Weekly Earnings Decompositions with Occupational Segregation.

\begin{tabular}{|c|c|c|c|c|}
\hline & $\begin{array}{c}\text { White Native/ } \\
\text { Non-White Natives }\end{array}$ & $\begin{array}{l}\text { White Native/White } \\
\text { Immigrants }\end{array}$ & $\begin{array}{c}\text { White Native/ } \\
\text { Non-White Immigrants }\end{array}$ & $\begin{array}{l}\text { White Immigrant/ } \\
\text { Non-White Immigrants }\end{array}$ \\
\hline Total Differential & 0.064 & -0.092 & 0.162 & 0.254 \\
\hline Occupational Segregation & 0.002 & -0.038 & 0.028 & 0.088 \\
\hline Characteristic & 0.005 & -0.042 & -0.118 & -0.084 \\
\hline Coefficient & 0.057 & -0.012 & 0.252 & 0.250 \\
\hline $\mathrm{Na}^{\mathrm{a}}$ & 1722 & 2588 & 2365 & 2365 \\
\hline
\end{tabular}

Notes $\mathbf{a}$ is the size of the non-base group. The size for white natives base group, (columns1-3) is 145276 and for white immigrants (column 4 ) is 2588. 
Appendix.

Table A1. Summary statistics of characteristics by Immigrant Status.

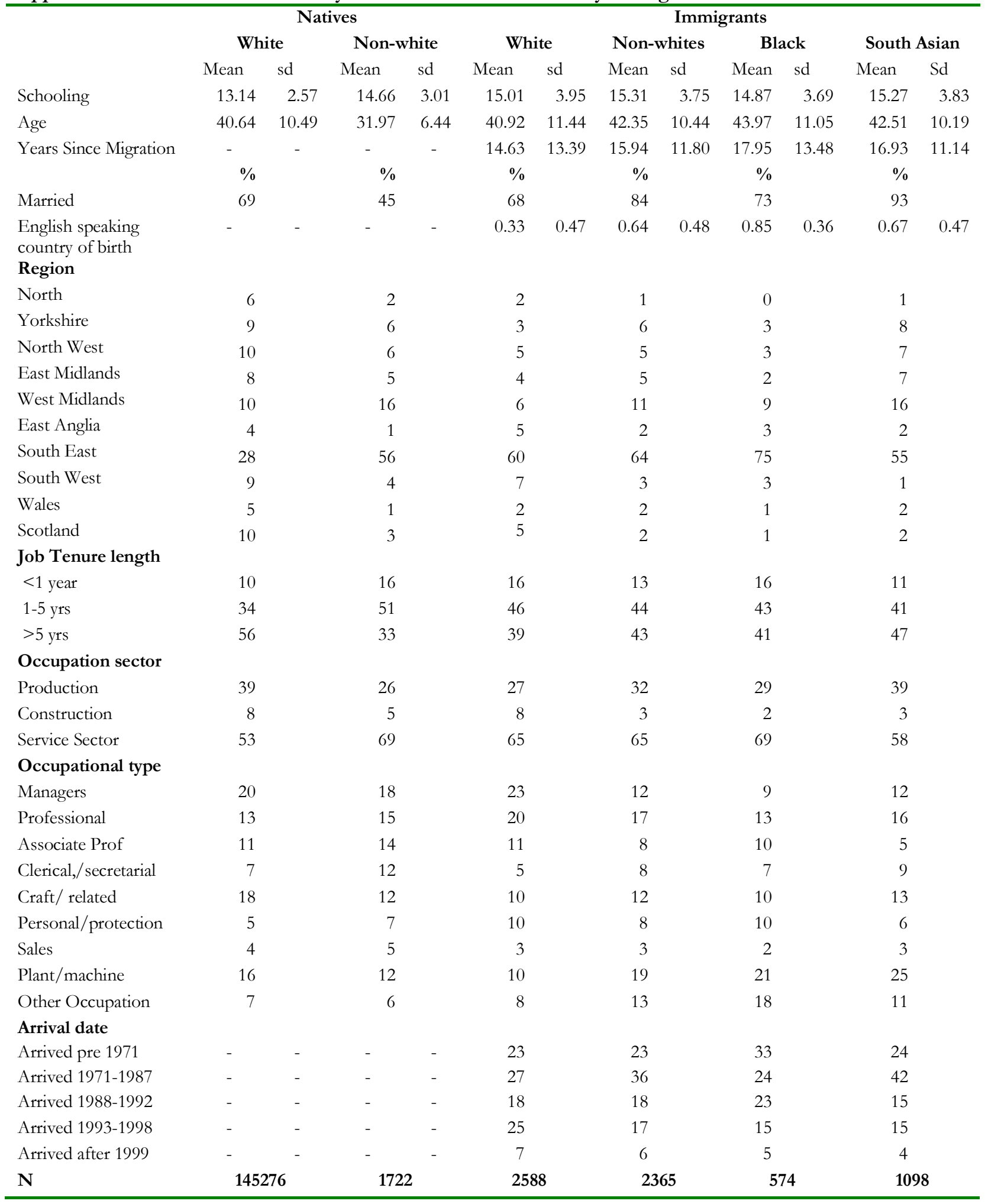

